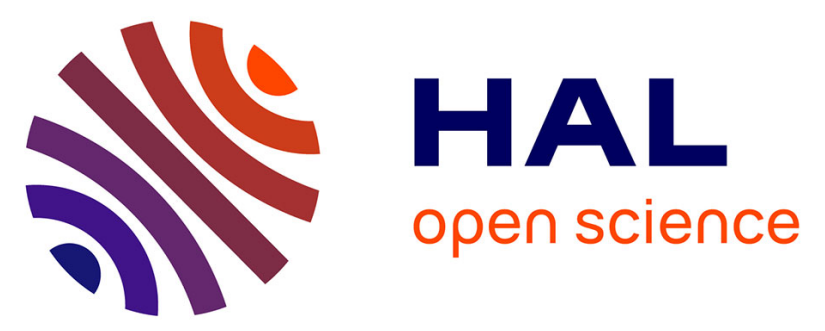

\title{
Primary Carboniferous and Permian paleomagnetic results from the Yili Block (NW China) and their implications on the geodynamic evolution of Chinese Tianshan Belt
}

Bo Wang, Yan Chen, Sheng Zhan, Liangshu Shua, Michel Faure, Dominique Cluzel, Jacques Charvet, Sébastien Laurent-Charvet

\section{To cite this version:}

Bo Wang, Yan Chen, Sheng Zhan, Liangshu Shua, Michel Faure, et al.. Primary Carboniferous and Permian paleomagnetic results from the Yili Block (NW China) and their implications on the geodynamic evolution of Chinese Tianshan Belt. Earth and Planetary Science Letters, 2007, 263 (3-4), pp.288-308. insu-00170195

HAL Id: insu-00170195

https://hal-insu.archives-ouvertes.fr/insu-00170195

Submitted on 23 Oct 2007

HAL is a multi-disciplinary open access archive for the deposit and dissemination of scientific research documents, whether they are published or not. The documents may come from teaching and research institutions in France or abroad, or from public or private research centers.
L'archive ouverte pluridisciplinaire HAL, est destinée au dépôt et à la diffusion de documents scientifiques de niveau recherche, publiés ou non, émanant des établissements d'enseignement et de recherche français ou étrangers, des laboratoires publics ou privés. 
Primary Carboniferous and Permian paleomagnetic results from the Yili Block (NW China) and their implications on the geodynamic evolution of Chinese Tianshan Belt

Bo Wang ${ }^{\mathrm{a}, \mathrm{b}, *}$, Yan Chen ${ }^{\mathrm{b}}$, Sheng Zhan ${ }^{\mathrm{b}, \mathrm{c}}$, Liangshu Shu ${ }^{\mathrm{a}}$, Michel Faure ${ }^{\mathrm{b}}$, Dominique Cluzel ${ }^{\mathrm{b}}$, Jacques Charvet $^{\mathrm{b}}$, Sébastien Laurent-Charvet ${ }^{\mathrm{d}}$

${ }^{a}$ Department of Earth Sciences, Nanjing University, 210093, Nanjing, China

${ }^{b}$ Institut des Sciences de la Terre d'Orléans, UMR CNRS 6113, Université d'Orléans, 45067, Orléans, France

${ }^{c}$ Key Laboratory of Orogenic Belts and Crustal Evolution, Peking University, 100871, Beijing, China ${ }^{d}$ Institut Géologique Albert-de-Lapparent, 95092, Cergy-Pontoise, France

* Corresponding author. Tel.: +86 258359 2921; fax: +86 2583686061 .

E-mail: wangbo1996@nju.org.cn or bo.wang@univ-orleans.fr (B. Wang).

\begin{abstract}
In order to better understand the tectonic role of the Yili Block on the Paleozoic evolution of the Chinese Tianshan Belt, we performed a primary paleomagnetic study on Carboniferous and Permian rocks from different areas in the Yili Block, NW of China. More than 320 sedimentary and volcanic samples were collected from 39 sites. Except for the Ordovician samples showing a weak and unstable magnetic remanence, the majority of this collection presents characteristic remanent magnetization carried by magnetite and hematite. In the study
\end{abstract}


area, though positive fold test has been observed on the Early Carboniferous rocks, a general remagnetization of these rocks has been identified and attributed to the Late Carboniferous magmatism Moreover, all Early and Late Carboniferous samples from the interior of the Yili Block yield stable and coherent magnetic directions with exhaustively reverse magnetic polarity. The Late Carboniferous $\left(\mathrm{C}_{2}\right)$ is considered as the magnetic remanence age since these rocks are covered or intruded by synchronous magmatic rocks of the Yili arc, which lasted until to $\sim 310 \mathrm{Ma}$. The $\mathrm{C}_{2}$ paleomagnetic pole is therefore calculated at $68.6^{\circ} \mathrm{N}, 290.6^{\circ} \mathrm{E}$ with $\mathrm{A}_{95}=6.4^{\circ}$ and $\mathrm{n}=15$. The Late Carboniferous rocks located close to a deformation zone present a consistentmagnetic inclination but significant different declination with respect to other areas and are suspected to have probably experienced a local rotation. Although no fold test can be performed due to the monoclinal bedding, stable magnetic components are isolated from Late Permian $\left(\mathrm{P}_{2}\right)$ red beds in the interior of the Yili Block with also a solo reverse magnetic polarity, the $\mathrm{P}_{2}$ paleomagnetic pole of the Yili Block has been, therefore, calculated from the characteristic remanent magnetization: $79.7^{\circ} \mathrm{N}, 172.0^{\circ} \mathrm{E}$ with $\mathrm{A}_{95}=11.3^{\circ}$ and $\mathrm{n}=5$. Keeping important uncertainties in mind, comparisons of the $\mathrm{C}_{2}$ and $\mathrm{P}_{2}$ paleomagnetic poles of the Yili Block with available coeval poles of Junggar, Tarim and Siberia indicate (1) no significant relative motion between the Yili and Junggar blocks since the Late Carboniferous, (2) no significant or weak latitudinal relative motion occurred since the Late Carboniferous among these blocks, but (3) the $46.2^{\circ} \pm 15.1^{\circ}$ and the $31.6^{\circ} \pm 15.1^{\circ}$ counterclockwise rotations of the Yili-Junggar blocks with respect to Tarim and Siberia took place during $C_{2}$ to $P_{2}$. These rotations are accommodated by the Permian dextral strike-slip faults along the northern and southern sides of Tianshan Belt and sinistral strike-slip faulting along the Erqishi Fault of Altay 
Belt, resulting in about $1000 \mathrm{~km}$ and $600 \mathrm{~km}$ lateral displacements in the Tianshan and Altay belts, respectively.

Keywords: Yili Block; Tianshan Belt; Paleozoic; paleomagnetism; rotation; strike-slip faulting

\section{Introduction}

The "Yili Block" represents a triangular shape sandwiched within the Tianshan Belt and widening westwards into Kazakhstan and Kyrgyzstan (Fig. 1a; [1]). It is considered as a microcontinent with a Precambrian basement separating the Tianshan Belt into northern and southern branches [2-5]. The Yili Block, therefore, occupies an important position for the understanding of the tectonic evolution of the Tianshan Belt. It is widely accepted that the Tianshan Belt is a Paleozoic orogenic belt due to multiphase accretion and amalgamation of various micro-continents, and magmatic arcs [6-9]. However, there are still controversies on procedures of amalgamation and chronological constraints. The Paleozoic Tianshan Belt is considered to be formed by subduction-collision processes [2-3, 10-11], i.e. the Yili Block and the Central Tianshan microcontinents (Fig. 1b) were rifted from the Tarim Plate in the Cambrian, and were re-accreted to Tarim during Ordovician to Early Carboniferous due to the multiphase subduction of oceanic crust. A southward subduction of an oceanic crust beneath the Yili Block during the Late Devonian to the Late Carboniferous terminated the convergent phases of mountain building in the Tianshan Belt. Nevertheless, some authors considered the Tianshan Belt as a part of the Altaids, which was mainly produced by strike-slip faulting [12-13]. Recently, some workers suggested that an oceanic crust existed in the southern Tianshan until the end of Permian on the basis of radiolarians found in South Tianshan 
ophiolitic mélange [14-15]. Besides, a Late Carboniferous to Early Permian continental rifting is also proposed according to geochemical and isotopic studies on the volcanic rocks in the Tianshan Belt [16]. These results suggest a divergent tectonics and a subsequent renewed convergence in the Tianshan area from Carboniferous to Permian, and therefore arise a controversy on the final evolution of the Tianshan Belt.

In addition, Permian transcurrent faulting is widely observed, especially ductile strike-slip faults are geologically well documented in the whole northern Xinjiang area [5, 17-20], including two main dextral strike-slip faults along the northern and the southern sides of the Tianshan Belt, and a sinistral strike-slip fault, the Erqishi Fault, in the Altay Belt. However, the southern fault of the Tianshan Belt was previously interpreted as a sinistral strike-slip fault [12, 21], which is also suggested on the basis of a significant westward deflection of magnetic declination [22-23], but this is not consistent with the geological and kinematic observations from Chinese Tianshan area [24-25], where no paleomagnetic data are available up to now to constrain this event and consequent lateral displacement.

In order to improve the understanding of the final orogenic procedures, this paleomagnetic study was carried out on Ordovician to Permian rocks from the Yili Block. The comparison of paleomagnetic data from this study with the previous results from Junggar, Tarim and Siberia blocks will better constrain the tectonic evolution of the Chinese Tianshan Belt during the Late Paleozoic time.

Figure 1.

\section{Geological setting and paleomagnetic sampling}

The Western Chinese Tianshan Belt is divided into several subunits, namely North 
Tianshan domain, Bole Block, Yili Block, Central Tianshan domain and South Tianshan mélange zone (Fig. 1b). In the Yili Block, the Precambrian basement is composed of Meso- to Neoproterozoic carbonates, clastic rocks and amphibolite facies metamorphic rocks developing along its northern and southern boundaries [26-27]. Early Paleozoic rocks consist of Cambrian to Ordovician carbonates and clastic rocks, and Silurian flysch in north of Yining area (Fig. 2a). The Devonian is mainly represented by terrigeneous rocks and arc-derived granitoids.

The Lower Carboniferous is, a ca. 3,500 m thick series of limestone, sandstone and shale with subordinate volcanic rocks, and the Upper Carboniferous consists of limestone intercalated with volcanoclastic sandstone and massive volcanic rocks (Fig. 2). Both Lower and Upper Carboniferous rocks are coeval with granitoids. Several geochronological studies on the volcanic and granitic rocks provide zircon U-Pb (SHRIMP and LA-ICPMS) ages ranging from $361 \mathrm{Ma}$ to $309 \mathrm{Ma}[5,28]$. Geochemical and isotopic studies suggest that the Yili Block was an active continental margin during the Late Devonian to Late Carboniferous [4, 28].

In the whole Western Chinese Tianshan Belt, Permian terrestrial sandstone and conglomerate unconformably overlie the older rocks (Fig. 2). Lower to Upper Permian bimodal volcanic and plutonic rocks are widespread throughout the Yili Block but form small occurrences (Fig. 2a; [17, 26, 29-30]). Strike-slip shear faults overprinted the Paleozoic sutures during Permian and underwent multiphase reactivation during the early Mesozoic [18-20, 31]. The Tianshan Belt is reactivated again by the Cenozoic intra-continental deformation and subsequently uplifted in response to the India-Asia collision [31-35].

In the Yili Block, more than 320 cores of 39 sites are paleomagnetically sampled from 5 localities (Fig. 2a; Table 1). Ordovician sandstone and pelitic limestone are collected from Axi 
section (Fig. 2a). Early to Late Carboniferous red sandstone, volcanoclastic sandstone, basalt and andesite are collected from Zhaosu, Xinyuan and Yuxi areas. In basalt and andesite that are exposed as massive rocks, the bedding (initial horizontal surface)is estimated from the underlying or overlying sedimentary rocks. Late Permian red beds are collected from the Gongliu area. Detailed sampling information may be found in Table 1. Depending on strata thickness, 6 to 12 cores were drilled from each site with a portable gasoline drill. Each core was orientated by both magnetic and solar compasses, when it was possible. The average of differences between these two azimuths is about $4.0^{\circ} \pm 3.4^{\circ}$, and this value was used for the orientation corrections to those samples measured only by magnetic compass as well as for the trends of bedding.

\section{Figure 2}

\section{Laboratory treatments}

Several methods were applied to magnetic mineralogical investigations: thermal magnetic (Curie point) experiment, the acquisition of Isothermal Remanent Magnetization (IRM) and the measurements of Anisotropy of Magnetic Susceptibility (AMS) carried out in Laboratoire de Magnétisme des Roches d'Orléans (LMRO), and magnetic hysteretic curves in Laboratoire du Paléomagnétisme of Institut de Physique du Globe de Paris (IPGP) at St Maur.

At least 6 cores were chosen from each site to carry out thermal and/or alternating magnetic field (AF) demagnetization in LMRO and IPGP. About 15 steps have been applied to progressive magnetic remanence cleaning with intervals varying from 20 to $150^{\circ} \mathrm{C}$ for thermal and 1 to $20 \mathrm{mT}$ for AF demagnetization.

The magnetic remanent directions were isolated by principal component analysis [36], the 
mean directions are computed by Fisher [37] spherical statistics using paleomagnetic software packages offered by Cogné [38] and PMGSC (version 4.2) by R. Enkin (unpublished).

\section{Figure 3.}

\section{Analysis results}

\subsection{Zhaosu area}

Two Carboniferous formations were sampled: Early Carboniferous Akeshake Formation $\left(\mathrm{C}_{1 \mathrm{ak}}\right)$ exposed in the south and Late Carboniferous Yilishijilike Formation $\left(\mathrm{C}_{2 \mathrm{y}}\right)$ [39] exposed in the north of the Zhaosu area (Fig. 2b; Table 1).

\section{Table 1.}

\section{Figure 4.}

\subsubsection{Clak Akeshake Formation}

Its lithology is composed of red sandstone occasionally bearing andesitic volcanic clasts, and yellow sandstone (Fig. 2b; Table 1). IRM measurement shows an abrupt increase with the total saturation at about $200 \mathrm{mT}$ (Figs. 3a-1 and 3a-2), indicating predominantly low-coercivity magnetic minerals in rocks. Thermal magnetic measurements display a sharp drop of magnetic susceptibility of sandstone and andesite at around $580^{\circ} \mathrm{C}$ (Fig. 4a), showing the existence of titanium-poor magnetite. Two components are isolated from 22 out of 25 measured samples. The low temperature components up to about $150^{\circ} \mathrm{C}$ show dispersed directions. Only a reverse polarity has been revealed from the high temperature component isolated from $250-300$ to $580^{\circ} \mathrm{C}$, indicating that the magnetic remanence in these rocks is mainly carried by magnetite. Figures 5b, 5c and Table 1 present site-mean directions in geographic (g) and stratigraphic (s) coordinates and an age-mean direction is calculated for this locality: $\mathrm{Dg}=207.3^{\circ}, \mathrm{Ig}=-57.8^{\circ}$, 
$k=10.5, \alpha_{95 \mathrm{~g}}=29.8^{\circ}$ and $\mathrm{Ds}=180.2^{\circ}, \mathrm{Is}=-40.9^{\circ}, k=46.9, \alpha_{95 \mathrm{~s}}=13.6^{\circ}$ with $\mathrm{n}=4$ (Table 1). Enkin's [40] DC fold test gives a positive answer to this formation with the maximum $\mathrm{k}$ value at $74.4 \%$ $\pm 49.7 \%$.

\section{Figure 5.}

\subsection{2. $C_{2 y}$ Yilishijilike Formation}

Five sites of red sandstones were sampled from a monoclinal section of about $200 \mathrm{~m}$ in stratigraphic thickness. IRM and magnetic hysteresis measurements of $\mathrm{C}_{2 \mathrm{y}}$ red sandstone (Figs. 3a-3 and 6a) suggest the occurrence of both low and high coercive magnetic minerals in the rocks. Thermal magnetic experiment also shows an evident drop of magnetic susceptibility from $550-620^{\circ} \mathrm{C}$ during the heating process (Fig. 4b) with two blocking temperatures at around $580^{\circ} \mathrm{C}$ and $680^{\circ} \mathrm{C}$ (Figs. 5d-5f), implying the presence of both magnetite and hematite. An age-mean direction has been calculated for this locality: $\mathrm{Dg}=151.6^{\circ}, \mathrm{Ig}=-61.2^{\circ}, \mathrm{kg}=48.0$, $\alpha_{95 \mathrm{~g}}=11.2^{\circ}$, and Ds $=164.7^{\circ}, \mathrm{Is}=-47.4^{\circ}, k \mathrm{~s}=50.7, \alpha_{95 \mathrm{~s}}=10.9^{\circ}$ with $\mathrm{n}=5$ (Table 1 ). No fold test could be concluded because of similar bedding, though the precision parameters $(k)$ are improved after tilt-corrections.

Figure 6.

\subsection{Xinyuan area}

Volcanoclastic sandstone and basalt of the Early Carboniferous Awulale Formation $\left(\mathrm{C}_{1 \mathrm{aw}}\right)$ [42] were collected from 11 sites in the south of Xinyuan County (Fig. 2a). Low-coercivity magnetic minerals are identified as the principal remanent carrier for tuffaceous sandstone and basaltic rocks on the basis of (a) abrupt IRM increase with a total magnetic saturation at about $200 \mathrm{mT}$ (Figs. 3b-1 and 3b-2), (b) Curie temperature point at around $580^{\circ} \mathrm{C}$ (Fig. 4c) and (c) 
narrow wasp-waisted hysteresis loops (Fig. 6b). But mixture of low and high coercivity magnetic minerals in rhyolitic sandstone is meanwhile identified by gradually increasing IRM curve (Fig. 3b-3) and wasp-waisted hysteresis loops (Fig. 6c).

Five sites of tuffaceous sandstone (Sites 532-536, Table 1) show very weak NRM (usually less than $1 \mathrm{~mA} / \mathrm{m})$. Demagnetisation on most of samples displays an important viscous component that may be cleaned up to $350^{\circ} \mathrm{C}$ and close to Present Earth Field (PEF; Fig. 7a). After the removal of the magnetic viscosity, most of specimens show random directions due to weak remanent intensity and few specimens show "stable" directions, which are also not far from PEF (Fig. 7b). So, no mean-site directions could be calculated.

Four sites of basalts (Sites 537 to 540, Table 1) show relatively stable and reverse magnetic components isolated at about $90 \sim 110 \mathrm{mT}$ or $580^{\circ} \mathrm{C}$ carried mainly by the titanium-poor magnetite (Figs. 7c and 7d; Table 1).(cette phrase repetes cela avant, je l'enleve) Tilt corrected directions are, however, much less clustered than in situ directions with a ratio of 0.06 for $\mathrm{ks} / \mathrm{kg}$, indicating a negative fold test (Figs. 7e and 7f).

The remaining 2 sites of red rhyolitic sandstoneJe pense c'est plus facile a discuter avec ce nom de lithologie? (Sites 541 and 542) show two blocking temperatures at around $580^{\circ} \mathrm{C}$ and $680^{\circ} \mathrm{C}$ (Figs. $7 \mathrm{~g}$ and $7 \mathrm{~h}$ ), implying the presence of the association of magnetite and hematite. A good consistency may be observed between high temperature components isolated from magnetite and hematite. No fold test may be applied as their bedding is constant. The directions isolated from high temperature component are more Consistent in stratigraphic coordinates with those of basalt than in geographic ones (Table 1), a locality-mean has been, therefore, calculated from these 2 sites in stratigraphic coordinates with 4 basalt sites in geographic ones 
(see Discussion for detail explanation; Table 1, Fig. 7e).

\section{Figure 7.}

\subsection{Gongliu area}

To the southeast of Gongliu County (Fig. 2a), an excellent exposure of E-W trending Late Permian red beds with a thickness larger than $2000 \mathrm{~m}$ is referred to as Xiaoshansayi Formation $\left(\mathrm{P}_{2 x}\right)$ on the basis of plant fossils [43]. Titanium-poor magnetite seems to be the main remanent carrier with minor proportion of hematite according to rapid IRM saturation at about $200 \mathrm{mT}$ (Fig. 3c), sharp drop of magnetic susceptibility at Curie point of about $580^{\circ} \mathrm{C}$ (Fig. 4d) and typical narrow wasp-waisted magnetite hysteresis (Fig. 6d). The directions carried by magnetite and hematite are well consistent to each other (Figs. 8a, 8c and 8d). All cores display two different remanence components, where the HTC yield a site-mean direction: $\mathrm{Dg}=189.3^{\circ}$, $\mathrm{Ig}=-16.2^{\circ}, \mathrm{kg}=111.7, \alpha_{95 \mathrm{~g}}=7.3^{\circ}$ and $\mathrm{Ds}=194.1^{\circ}, \mathrm{Is}=-60.7^{\circ}, \mathrm{ks}=76.1, \alpha_{95 \mathrm{~s}}=8.8^{\circ}$ with $\mathrm{n}=5$ (Table 1 ; Figs. $8 \mathrm{e}$ and $8 \mathrm{f}$ ). The fold test is inconclusive as the variation of bedding is not important enough.

Figure 8.

\subsection{Yuxi area}

Late Carboniferous variable color sandstones are interbedded with andesite flows near the Yuxi pass (Fig. 2a). Six sites of andesite and sandstone were collected from the Tuergong Formation $\left(\mathrm{C}_{2 \mathrm{t}}\right.$ [44], Table 1). Linear or sub-linear IRM curves show characteristic high coercive minerals (Fig. 3d), thermal magnetic experiments identified hematite as the corresponding ones (Fig. 4e). Stable high temperature components isolated from magnetic demagnetisation yield a mean direction at: $\mathrm{Dg}=211.5^{\circ}, \mathrm{Ig}=-36.4^{\circ}, \mathrm{kg}=354.3, \alpha_{95 \mathrm{~g}}=3.6^{\circ}$ and 
$\mathrm{Ds}=223.1^{\circ}, \mathrm{Is}=-40.8^{\circ}, \mathrm{ks}=350.1, \alpha_{95 \mathrm{~s}}=3.6^{\circ}$ with $\mathrm{n}=6$ (Table 1$)$.

\subsection{Axi area}

Middle Ordovician pelitic rocks of the Lelengeledaban Formation $\left(\mathrm{O}_{21}\right)$ [45] are sampled from 8 sites in Axi area (Fig. 2a). Magnetite and hematite are suggested to be the main magnetic minerals by IRM studies with a very weak remanent intensity (Fig. 3e). Thermal magnetic experiments show an obvious oxidation and an important proportion of magnetite may be formed during the heating (Fig. 4f). The NRM of pelitic rocks is very heterogeneous and varies from 0.096 to $6.98 \mathrm{~mA} / \mathrm{m}$ with an average of $0.25 \mathrm{~mA} / \mathrm{m}$. No any stable component may be isolated after the removal of viscous magnetization.

\section{Discussion}

Except for the samples from the Axi section that yield no reliable magnetic component, laboratory magnetic mineralogical analyses and thermal/AF demagnetisations have successfully isolated two magnetic components, namely viscous and characteristic remanent magnetizations from 4 out of 5 Late Paleozoic sections. The viscous one clearly records the recent geomagnetic field with a negative fold test $\left(\mathrm{Dg}=348.4^{\circ}, \mathrm{Ig}=67.1^{\circ}, \mathrm{kg}=15.9, \alpha_{95 \mathrm{~g}}=3.1^{\circ}\right.$ and $\mathrm{Ds}=350.2^{\circ}, \mathrm{Is}=52.9^{\circ}, k \mathrm{~s}=3.3, \alpha_{95 \mathrm{~s}}=7.9^{\circ}$ with $\mathrm{n}=185$ samples). However, the stable titanium-poor magnetite and hematite have been identified as principal magnetic remanent carriers for the characteristic remanent magnetization. The following evidences strengthen our argument that the ChrM can be used for tectonic implications: (1) the positive fold test observed from Zhaosu area; (2) the solo reversed polarity with significantly distinguishable 
mean directions from PEF as well other Mesozoic and Cenozoic ones [46-47]. However, as mentioned above, this area has experienced multiphase tectonic and magmatic events. Before putting forward their tectonic implications of these new paleomagnetic data, their reliability and magnetic remanence age should be discussed.

\section{Figure 9.}

\subsection{Reliability and magnetic remanence age}

In order to acknowledge on the degree of deformation for our paleomagnetic collection, Anisotropy of Magnetic Susceptibility (AMS) measurements were performed. Figure 9 reveals a relatively weak anisotropy degree with $\mathrm{P}^{\prime}<1.05$ for most of samples though some from Yuxi and Axi seem to have higher and heterogeneous P' values. This observation indicates that the sampling zones have not suffered severe latter deformation at least at the hand-sample scale.

Table 1 shows rock ages of our collection ranging from Early Carboniferous to Late Permian. The exclusive reversal polarity revealed from ChrM seems consistent with the Permo-Carboniferous Reversed Superchron (PCRS), e.g. by [48]. However, as described in the Geological Setting section, some Late Carboniferous volcanic rocks overlie the Lower Carboniferous sedimentary rocks and, the folding is younger that the volcanism. Furthermore, Carboniferous-Permian granitic plutons are often found near the sampling sites, thus we cannot simply conclude that the remanence isolated from ChrM is primary or calculate age-mean directions and corresponding paleomagnetic poles.

For the Late Permian rocks of Gongliu area, their age is well constrained by abundant plant fossils and they are unconformably overlain well dated Early Permian volcanic rocks. Though the statistic precision parameter $(k)$ slightly decreases, the fold test is not conclusive due to 
weak bedding variation. Thus, the solo reversed polarity from about $300 \mathrm{~m}$-thick section may indicate that the magnetic remanence has been acquired before $\sim 250 \mathrm{Ma}$ (the upper limit of PCRS), i.e. similar to the Late Permian rock age. Thus, a paleomagnetic pole has been calculated for $\mathrm{P}_{2}$ period: $\lambda=79.7^{\circ} \mathrm{N}, \phi=172.0^{\circ} \mathrm{E}, \mathrm{A}_{95}=11.3^{\circ}$ with $\mathrm{n}=5$ (Table 2).

Four sites from the Early Carboniferous Akeshake formation $\left(\mathrm{C}_{1 \mathrm{ak}}\right)$ show also only one reversed polarity with a positive fold test. If the paleomagnetic collection is representative for this geological period, the normal polarity should be identified by demagnetisation since the $\mathrm{C}_{1}$ and $\mathrm{C}_{2}$ limit is close to the lower limit of PCRS ( 325 Ma). Geologically, Early Permian intra-continental volcaniclastic rocks $[17,26,30]$ overlay unconformably on the folded Late Carboniferous volcano-sedimentary rocks in the Yili Block, indicating that folding occurred before Early Permian magmatism. Moreover, the site-mean directions of the Early Carboniferous are very close to those of the Late Carboniferous, and both of them are obviously different from the direction of the Late Permian red-beds (Table 1). This unconformity and positive fold test exclude the possibility of an Early Permian overprint. Additionally, since both $\mathrm{C}_{1}$ and $\mathrm{C}_{2}$ sandstones are covered by homochronous volcanic rocks and intruded by granites, which are dated by zircon U-Pb from $361 \pm 6 \mathrm{Ma}$ to $309 \pm 3 \mathrm{Ma}[5,28]$, suggesting that the thermal event corresponding to the Yili magmatic arc lasted until the end of Late Carboniferous. This prominent thermal event might be responsible for remagnetization of the pre-existing rocks . It is, therefore, reasonable to suggest that both Early and Late Carboniferous rocks of Zhaosu area recorded an identical paleomagnetic direction during the Late Carboniferous magmatism in the Yili Block. Thus, an overall mean direction is calculated for both Early and Late Carboniferous sites: $\mathrm{Dg}=176.7^{\circ}, \mathrm{Ig}=-62.7^{\circ}, \mathrm{kg}=13.0, \alpha_{95 \mathrm{~g}}=14.7^{\circ}$ and $\mathrm{Ds}=172.0^{\circ}$, 
$\mathrm{Is}=-44.8^{\circ}, \mathrm{ks}=40.4, \alpha_{95 \mathrm{~s}}=8.2^{\circ}$ (Table 1; Figs. $\left.5 \mathrm{~b}-5 \mathrm{c}\right)$.

A similar situation occurs for the Early Carboniferous rocks from Xinyuan area. All reliable directions of basalts from Sites 537-540 show a reversed polarity in geographic coordinate but with a negative fold test (Table 1; Figs. 7e and 7f), indicating latter overprint instead of primary magnetization for these Early Carboniferous samples. Due to the high occurrence of volcanic rocks dated at $313 \pm 4 \mathrm{Ma}$ [28] and granites at $315 \pm 3$ and $309 \pm 3 \mathrm{Ma}$ in the sampling area [5] (Fig. 2a), it is reasonable to propose a Late Carboniferous ( $310 \mathrm{Ma})$ age for the thermal remagnetization. Concerning the two rhyolitic sandstone sites (Sites 541-542), although the reversal polarity is identified in both coordinates, their directions in stratigraphic coordinates seem more consistent with either the in-situ directions of 4 volcanic sites or the locality-mean direction of Zhaosu area. The age of the rhyolitic sandstone is, in fact, questionable. No any direct age constraint has been documented from this formation although referred to as Early Carboniferous $[26,42]$. In the point of view of regional tectonics and stratigraphic correlation, it is clear that the age of the rhyolitic sandstone is younger than that of the basalt dated at $354 \pm 5 \mathrm{Ma}$ (zircon U-Pb SHRIMP by Zhu et al. [28]). Moreover, no any direct contact between these two lithostratigraphic units can be observed in the field, stratigraphic and structural knowledge allows us to exclude a syncline structure and to favour an unconformable contact. According to the above arguments, it is not unreasonable to consider that the rhyolitic sandstone is Late Carboniferous in age. Thus, 4 in-situ paleomagnetic directions of basalts and 2 tilt-corrected directions of rhyolitic sandstones are used to calculate an average direction at: $\mathrm{D}=165.3^{\circ}, \mathrm{I}=-36.4^{\circ}, \mathrm{k}=37.7, \alpha_{95}=11.0^{\circ}$ for the Late Carboniferous magnetization from Xinyuan area (Table 1; Fig. 7e). 
As to paleomagnetic results from Yuxi area, 6 Late Carboniferous sites present well grouped reversal directions without fold test due to monoclinal attitude of the bedding (Table 1). The magnetic inclinations from this locality are consistent with those from Zhaosu and Xinyuan areas, but this area shows a significant different declination with respect to other two. As this sampling locality is situated nearby a tectonic zone (Fig. 2a), the difference in declination may be explained by a local rotation of the Yuxi sampling zone with respect to the Yili Block.

According to above direction analyses and geologic arguments, a $\mathrm{C}_{2}$ paleomagnetic pole may be calculated for the Yili Block from Zhaosu and Xinyuan areas: $\lambda=68.6^{\circ} \mathrm{N}, \phi=290.6^{\circ} \mathrm{E}$, $\mathrm{A}_{95}=6.1^{\circ}$ with $\mathrm{n}=15$ (Table 2$)$.

Figure 10.

\subsection{Comparisons of the paleomagnetic data from Yili with other adjacent blocks}

Up to now, no paleomagnetic data were documented from the Yili Block, except some data obtained from Carboniferous-Permian rocks in the western Tianshan of Kyrgyzstan [22-23, 49]. Most of these data were derived from the deformation belt, e.g. "North Tianshan tectonic zone" located in the extremely northwestern part of the Tianshan Belt (Fig. 1a). These studied areas cannot be considered as a part of a rigid block, some deflections of declination with respect to the reference blocks (e.g. Tarim and Siberia) may be, therefore, interpreted as the result of strike-slip faulting within the orogenic belt, rather than the representative rotation of a rigid body [23]. In fact, the Yili Block is accepted as a microcontinent with a Precambrian basement $[2-5,11]$, it extends westwards into Kazakhstan with an unclear boundary, and its eastern boundaries are the southern and northern branches of the Tianshan range (Fig. 1). These boundaries were highly deformed during the Tianshan orogeny, but the interior of the block is 
much less deformed. This agrees well with the good consistency between the $\mathrm{C}_{2}$ paleomagnetic results from Zhaosu and Xinyuan areas located near to the center of the Yili Block but distant from about $200 \mathrm{~km}$ (Figs. 2a, 5f and 7e). Thus, the paleomagnetic poles derived from these areas are representative for the whole Yili block (Table 2).

In order to understand the kinematic relationships during the Late Paleozoic between the Yili Block and adjacent ones, previous paleomagnetic results on the Tarim, Junggar and Siberia blocks are analysed and listed in Table 2. Late Carboniferous and Late Permian poles of the Tarim Block have been well documented by numerous studies [50-59], these data are very consistent with each other within the relatively weak uncertainty (Table 2), the Late Carboniferous and Late Permian mean poles are recalculated at $51.5^{\circ} \mathrm{N}, 169.1^{\circ} \mathrm{E}, \mathrm{A}_{95}=7.7^{\circ}$ and $66.8^{\circ} \mathrm{N}, 184.1^{\circ} \mathrm{E}, \mathrm{A}_{95}=4.9$, respectively. Van der Voo [60] presented Late Carboniferous and Late Permian paleomagnetic poles of Siberia Block (Table 2). As for the Junggar Block, few results have been reported from the Urumqi area and the northwestern Junggar basin (Fig. 1b; [61-64]), but the available data are quite dispersed/scattered?, and the ages of magnetization are often undetermined (Table 2). For example, the paleomagnetic results from the southern and northwestern parts of the Junggar basin by Li et al. [62] are not consistent, an important second overprint is proposed, the ages of the primary or secondary magnetization are roughly restricted between Late Carboniferous and Permian, i.e. a long and variable interval from 20 to 75 Ma. Such an uncertainty in age and variability in paleomagnetic pole make them unfeasible to compare with those from other blocks. Only one relatively reliable paleomagnetic pole derived from the northwestern part of the Junggar basin [62] may be considered for the Late Carboniferous period (Table 2). Concerning the Late Permian period, two paleomagnetic poles 
have been obtained from Urumqi [63] and Tianchi areas [64] (Table 2). However, the former study shows that only 26 (4 sites) out of 78 samples from Urumqi display directly observable directions, and the other samples are analysed by the grand circle technique with an important uncertainty. In addition, magnetic remanence of these Late Permian sediments is viscous, magnetic directions are relatively dispersed within and among sites, the paleomagnetic pole is calculated with specimens instead of by site-mean directions. Paleomagnetic directions derived from the Tianchi section seem to be relatively stable, and passed a positive fold test, therefore, these latter results are accepted for the Late Permian paleomagnetic pole of the Junggar block (Table 2).

Figure 10a shows the paleomagnetic poles of each block for each geologic epoch. The Late Carboniferous pole of the Yili Block is very close to that of Junggar with an angular difference of $7.7^{\circ} \pm 6.6^{\circ}$, but far away from coeval poles of Tarim $\left(120.5^{\circ} \pm 7.0^{\circ}\right)$ and Siberia $\left(119.0^{\circ} \pm 5.1^{\circ}\right.$; Fig. 10b). Small circles centred at the sampling site show no significant latitudinal differences of $4.2^{\circ} \pm 6.9^{\circ}$ between Yili Block and Junggar, and relatively weak latitudinal differences of $12.8^{\circ} \pm 7.1^{\circ}$ between Yili and Tarim, and of $7.0^{\circ} \pm 5.5^{\circ}$ between Yili and Siberia (Fig. 10b). The case will be changed when looking at relative rotations. The Yili Block doesn't show any significant relative rotation with respect to Junggar $\left(2.2^{\circ} \pm 9.3^{\circ}\right)$, but significant counterclockwise $(\mathrm{CCW})$ rotations of $60.0^{\circ} \pm 10.6^{\circ}$ and $70.0^{\circ} \pm 7.4^{\circ}$ with respect to Tarim and Siberia, respectively (Fig. 10b). The Late Permian poles of Yili Block, Junggar and Tarim become almost consistent within uncertainty $\left(<12.1^{\circ} \pm 9.9^{\circ}\right)$, but they are significantly different from the pole of Siberia $\left(>24.1^{\circ} \pm 6.8^{\circ}\right.$; Fig. 10c). Latitudinal differences of the Yili Block become insignificant of $4.8^{\circ} \pm 7.7^{\circ}, 7.4^{\circ} \pm 7.7^{\circ}$ and $3.3^{\circ} \pm 8.6^{\circ}$ with respect to Junggar, Tarim and 
Siberia, respectively (Fig. 10c). The CCW rotation of the Yili Block keeps the same of $1.5^{\circ} \pm$ $15.6^{\circ}$ with Junggar, becomes insignificant of $13.8^{\circ} \pm 15.6^{\circ}$ with Tarim and remains still important of $38.4^{\circ} \pm 17.3^{\circ}$ with Siberia (Fig. 10c).

\section{Table 2.}

\subsection{Tectonic implications}

According to theabove presented paleomagnetic data analyses, the small observed latitudinal differences of the Yili Block with respect to Junggar, Tarim and Siberia are within the error bars. This result indicates that no important relative latitudinal movement between the Yili Block and the other Central Asia blocks took place since the Late Carboniferous. This observation is quite consistent with geological evidences, from which the major orogenic event in the Chinese Tianshan Belt which is due to the convergences among Junggar, Yili Block and Tarim is considered to have been completed at the end of the Late Carboniferous [2, 5, 10-11]. The remaining small convergent latitudinal differences of the Yili Block relative to the other blocks since Late Permian likely correspond to the Cenozoic intra-continental subduction of Tarim and Junggar beneath the Tianshan Belt, [30, 32-35, 46].

Figure 11 .

\section{Figure 12.}

The good consistency between the paleomagnetic poles from the Yili Block and Junggar may indicate that these two blocks were welded since the Late Carboniferous and they might be paleomagnetically considered as a single block since that time. In another words, if there is any relative motion between them, it should be under the paleomagnetic uncertainty. As described above, the significant polar differences of the Yili Block with respect to Tarim and Siberia 
essentially reveal the CCW rotations of Yili-Junggar related to Tarim and Siberia. These CCW rotations are estimated of $60.0^{\circ} \pm 10.6^{\circ}$ and $70.0^{\circ} \pm 7.4^{\circ}$ since the $C_{2}$ period, and of $13.8^{\circ} \pm 15.6^{\circ}$ and $38.4^{\circ} \pm 17.3^{\circ}$ since the $\mathrm{P}_{2}$ period (Fig. 10). These observations allow us to estimate the relative rotation from Late Carboniferous to Late Permian by subtracting the relative motion since $\mathrm{P}_{2}$ from that since $\mathrm{C}_{2}$. Consequently, during the $\mathrm{C}_{2}-\mathrm{P}_{2}$ interval, the $\mathrm{CCW}$ rotation of the Yili-Junggar Block attained about $46.2^{\circ} \pm 15.1^{\circ}$ with respect to Tarim, and $31.6^{\circ} \pm 15.1^{\circ}$ to Siberia. Since Late Permian, this CCW rotation of Yili-Junggar Block with respect to Tarim becomes insignificant within uncertainty $\left(13.8^{\circ} \pm 15.6^{\circ}\right)$, but remains still significant of $38.4^{\circ} \pm$ $17.3^{\circ}$ with respect to Siberia. As all four blocks were amalgamated at the end of Late Carboniferous, the relative rotations between blocks were accommodated by strike-slip faulting along their boundaries and therefore resulted in lateral displacements. The northern and southern boundaries of the Yili Block correspond to two ductile shear zones (Fig. 1b). To the north, the North Tianshan Fault (NTF) $[5,29,65]$ extends eastward merging in the Main Tianshan Shear Zone (MTSZ) [19-20]. The kinematics of the ductile shearing along the MTSZ and NTF is dextral [5, 19-20] (Figs. 1b, 2a and 11a). To the south, the Nalati Fault (NF) [65] and Qingbulak Fault $[2,10]$ (QF) extend sub-parallelly to the NTF and MTSZ. The Nalati Fault, also regarded as the Nikolaev Tectonic Line [21], is the most significant structure. Previous studies proposed a left-lateral slip $[12,17,23]$, but field structural analyses based on kinematic indicators suggest a right-lateral strike-slip faulting [24-25] (Fig. 11b). In order to account for the paleomagnetic and structural data, simplified paleogeographic reconstructions of these rotation patterns are proposed in Figure $12 \mathrm{a}, 12 \mathrm{~b}$ and $12 \mathrm{c}$ at $\mathrm{C}_{2}, \mathrm{P}_{2}$ and Present periods, respectively. The quantitative estimation of the lateral displacements corresponding to the 
$\mathrm{CCW}$ rotation of Yili-Junggar with respect to Tarim, requires the definition of an Euler pole of relative motion, around which, one crustal block rotates with respect to another along a major fault. In the Tianshan Range, two strike-slip shear zones form an arcuate belt separating Junggar to the north from Tarim to the south (Fig. 12c). The best fitting small circle passing through this belt allows us to estimate the Euler pole position at about $55^{\circ} \mathrm{N}, 92^{\circ} \mathrm{E}$ with a radius of about $13^{\circ}$ (distance between the pole and the belt; Fig. 12c). The $46.2^{\circ} \pm 15.1^{\circ} \mathrm{CCW}$ rotation of Junggar-Yili with respect to Tarim, therefore, corresponds to a right-lateral displacement of $1160 \pm 380 \mathrm{~km}$ along these strike-slip faults (Figs. 12a and 12b). This sum of motion may be explained by two opposite displacements of Yili-Junggar and Tarim along the Tianshan shearing zones from $\mathrm{C}_{2}$ to $\mathrm{P}_{2}$. During this period, Yili-Junggar experienced an eastward movement of $670 \pm 320 \mathrm{~km}$, and Tarim went westwards of $360 \pm 270 \mathrm{~km}$, with respect to Siberia, respectively (Figs. 12a and 12b). It is worth to note that the Central Tianshan located between the Yili Block and Tarim is not involved in our simplified reconstruction.

Similarly, the CCW rotation of Yili-Junggar relative to Siberia is accommodated by a sinistral shearing along the Erqishi ductile shear zone in the Altay Belt (Figs. 1b, 12a, 12b and 12c). A sinistral kinematics has been widely recognized by structural analyses [17-20] (Fig. 11c). On the basis of the curved shape of the shear zone (Fig. 12), an Euler pole is estimated at $56^{\circ} \mathrm{N}, 101^{\circ} \mathrm{E}$ with a radius of about $11^{\circ}$ (Fig. 12c). The $31.6^{\circ} \pm 15.1^{\circ} \mathrm{CCW}$ rotation of Junggar-Yili with respect to Siberia observed in this study corresponds to a displacement of 670 $\pm 320 \mathrm{~km}$ along the Erqishi Fault during Late Carboniferous to Late Permian (Fig. 12b), and the remaining $38.4^{\circ} \pm 17.3^{\circ} \mathrm{CCW}$ rotation implies a continuous displacement of $820 \pm 370 \mathrm{~km}$ that occurred in post-Permian tim (Fig. 12b). This may indicate that Yili-Junggar continued its 
eastward movement together with Tarim after the Permian (Figs. 12b and 12c). This motion essentially ended up before the Cretaceous because Cretaceous paleomagnetic data from Junggar, Mongolia as well as Siberia do not show significant differences among them $[47,66]$.

Ar-Ar geochronological studies on the ductile deformed rocks from shear zones indicate that Tianshan dextral strike-slip faulting took place during 290 240 Ma [19-20, 24, 29]. Erqishi sinistral strike-slip faulting is proposed to occur from $290 \mathrm{Ma}$ to $240 \mathrm{Ma}$ [20], and continued through Triassic to Early Jurassic [17]. Such large-scale and contemporaneous displacements along the southern right-lateral and northern left-lateral boundaries of Yili-Junggar blocks enable us to suggest an eastward wedging of Yili-Junggar blocks between Tarim and Siberia. Meanwhile, further paleomagnetic and geological studies on Early Permian of the Yili and Junggar blocks is needed to better constrain the timing of relative motions as well as the mechanism of such tectonics.

\section{Conclusions}

This first paleomagnetic study is performed on sedimentary and volcanic rocks from the Yili Block. Magnetic mineralogical analyses show titanium-poor magnetite and hematite as the principal remanence carriers. Except the samples from the Axi area showing weak and unstable magnetic remanence, most of samples demagnetised by thermal and $\mathrm{AF}$ techniques demonstrate both viscous and stable components, the former gives a magnetic direction close to $\mathrm{PEF}$ and the latter presents characteristic remanent magnetization. The reversal polarity is exhaustively obtained from these Early and Late Carboniferous rocks and Late Permian red beds. A general remagnetization of Early Carboniferous rocks has been observed due to the 
Late Carboniferous Yili arc magmatism. Two paleomagnetic poles of Late Carboniferous and Late Permian ages for the Yili Block are calculated from stable directions. Keeping in mind the important uncertainties, comparisons of both poles to the available coeval poles of Tarim, Junggar and Siberia indicate that (1) The consistency of poles from Yili and Junggar implies no or small relative motion between them since the Late Carboniferous; (2) no significant or small relative latitudinal movement occurred between these 4 blocks since Late Carboniferous; (3) $46.2^{\circ} \pm 15.1^{\circ}$ and $31.6^{\circ} \pm 15.1^{\circ}$ counterclockwise rotations of the Yili-Junggar blocks with respect to Tarim and Siberia, respectively, took place from Late Carboniferous to Late Permian. These rotations correspond to the eastward motions of Yili-Junggar Block with respect to Tarim $(1160 \pm 380 \mathrm{~km})$ along the dextral strike-slip faults in the Tianshan Belt and to Siberia $(670 \pm 320$ $\mathrm{km})$ along the left-lateral Erqishi Fault in the Altay belt. These conclusions are supported by both field structural and kinematic observations as well as geochronologic studies in these tectonic zones.

\section{Acknowledgement}

This study has been supported by French-Chinese Advanced Research Program (PRA T05-02, Y. CHEN \& Q.C. WANG). French Embassy in Beijing is appreciated for financing part of research of the first author in France. Constructive suggestions provided by an anonymous reviewer have significantly improved the original manuscript.

\section{References}


[1] R.J. Enkin, Y. Chen, V. Courtillot, J. Besse, L. Xing, Z. Zhang, Z. Zhuang, J. Zhang, A Lower Cretaceous pole from South China and the Mesozoic hairpin turn of the Eurasian apparent polar wander path, J. Geophys. Res. 96 (1991) 4007-4028.

[2] M.B. Allen, B.F. Windley, C. Zhang, Paleozoic collisional tectonics and magmatism of the Chinese Tien Shan, Central Asia, Tectonophysics 220 (1992) 89-115.

[3] C.M. Chen, H.F. Lu, D. Jia, D.S. Cai, S.M. Wu, Closing history of the southern Tianshan oceanic basin, western China: an oblique collisional orogeny, Tectonophisics 302 (1999) 23-40.

[4] B. Wang, L.S. Shu, D. Cluzel, M. Faure, J. Charvet, Geochemical Constraints on Carboniferous Volcanic rocks of Yili Block (Xinjiang, NW China); implication on tectonic evolution of Western Tianshan, J. Asian Earth Sci. 29 (2007) 148-159.

[5] B. Wang, M. Faure, D. Cluzel, L.S. Shu, J. Charvet, S. Meffre, Late Paleozoic tectonic evolution of the northern West Tianshan, NW China, Geodin. Acta 19(3-4) (2006) 237-247.

[6] R.G. Coleman, Continental growth of northwest China, Tectonics 8 (3) (1989) 621-635.

[7] Y.S. Shi, H.F. Lu, D. Jia, D.G. Howell, Paleozoic plate tectonic evolution of the Tarim and western Tianshan Regions, Western China, Int. Geol. Rev. 36 (1994) 1058-1066.

[8] L.S. Shu, H.F. Lu, J. Charvet, S. Laurent-Charvet, D.H. Yin, Paleozoic accretionary terranes in Northern Tianshan, NW China, Chin. Geochem. 19 (3) (2000) 193-202.

[9] L.S. Shu, J. Charvet, H.F. Lu, S. Laurent-Charvet, Paleozoic accretion-collision events and kinematics of ductile deformation in the central-southern Tianshan Belt, China, Acta Geol. Sin. 76 (3) (2002) 308-323.

[10] B.F. Windley, M.B. Allen, C. Zhang, Z.Y. Zhao, G.R. Wang, Paleozoic accretion and 
Cenozoic redeformation of the Chinese Tien Shan range, Central Asia, Geology 18 (1990) $128-131$.

[11] J. Gao, M.S. Li, X.C. Xiao, Y.Q. Tang, G.Q. He, Paleozoic tectonic evolution of the Tianshan orogen, northwestern China, Tectonophysics 287 (1998) 213-231.

[12] A.M.C. Sengör, B.A. Natal'in, V.S. Burtman, Evolution of the Altaid tectonic collage and Paleozoic crust growth in Eurasia, Nature 364 (1993) 299-307.

[13] A.M.C. Sengör, B.A. Natal'in, Palaeotectonics of Asia: Fragments of a synthesis, In: A. Yin, M. Harrison (Eds.), The tectonic evolution of Asia, Rubey Colloquium, Cambridge University Press, Cambridge, 1996, pp. 486-640.

[14] Y.J. Li, Z.M. Wang, H.R. Wu, Z.B. Huang, Z.J. Tan, J.C. Luo, Discovery of radiolarian fossils from the Aiketik group at the western end of the South Tianshan Mountains of China and its implications, Acta Geol. Sin. 76 (2) (2002) 146-154.

[15] Y.J. Li, L.D. Sun, H.R. Wu, G.Y. Zhang, G.L. Wang, Z.B. Huang, Permo-Carboniferous radiolarians from the Wupata'erkan group, Western South Tianshan, Xinjiang, China, Acta Geol. Sin. 79 (1) (2005) 16-23.

[16] L.Q. Xia, X.Y. Xu, Z.C. Xia, X.M. Li, Z.P. Ma, L.S. Wang, Petrogenesis of Carboniferous rift-related volcanic rocks in the Tianshan, northwestern China, Bull. Geol. Soc. Am. 116 (3-4) (2004) 419-433.

[17] M.B. Allen, A.M.C. Sengör, and Natal'in, B.A., Junggar, Turfan and Alakol basins as Late Permian to ?Early Triassic extensional structures in a sinistral shear zone in the Altaid orogenic collage, Central Asia, J. Geol. Soc. Lond. 152 (1995) 327-338.

[18] L.S. Shu, J. Charvet, L.Z. Guo, H.F. Lu, S. Laurent-Charvet, A large-scale Palaeozoic 
dextral ductile strike-slip zone: the Aqqikkudug-Weiya zone along the northern margin of the Central Tianshan belt, Xinjiang, NW China, Acta Geol. Sin. 73 (2) (1999) 148-162.

[19] S. Laurent-Charvet, J. Charvet, L.S. Shu, R.S. Ma, H.F. Lu, Palaeozoic late collisional strike-slip deformations in Tianshan and Altay, eastern Xinjiang, NW China, Terra Nova 14 (4) (2002) 249-256.

[20] S. Laurent-Charvet, J. Charvet, P. Monie, L.S. Shu, Late Paleozoic strike-slip shear zones in eastern Central Asia (NW China): new structural and geochronological data, Tectonics 22 (2) (2003) 1099-1101.

[21] V.S. Burtman, Structural geology of variscan Tien Shan, USSR, Am. J. Sci. 275(A) (1975) 157-186.

[22] L.M. Bazhenov, A. Chauvin, M. Audibert, N.M. Levashova, Permian and Triasic paleomagnetism of the southwestern Tien Shan: timing and mode of tectonic rotations, Earth Planet. Sci. Lett. 118 (1993) 195-212.

[23] M.L. Bazhenov, V.S. Burtman, A.V. Dvorova, Permian paleomagnetism of the Tien Shan fold belt, Central Asia: Post-collisional rotation and deformation, Tectonophysics 312 (2-4) (1999) 303-329.

[24] A.Yin, S.Y. Nie, A Phanerozoic palinspastic reconstruction of China and its neighboring regions, in: A. Yin, Harrison, M. (Eds.), The Tectonic Evolution of Asia, Rubey Colloquium, Cambridge University Press, Cambridge, 1996, pp. 442-485.

[25] B. Wang, M. Faure, L.S. Shu, K. de Jong, D. Cluzel, J. Charvet, S. Meffre, G. Ruffet, Tectonics of the Yili Block in the southern part of the Western Chinese Tianshan, and its Paleozoic geodynamic evolution, Tectonics, submitted.[26] XBGMR (Xinjiang Bureau of 
Geology and Mineral Resources), Regional geology of Xinjiang Uygur Autonomy Region. Geology Publishing House, Beijing, 1993 (in Chinese with English abstract).

[27] Y.B. Chen, A.Q. Hu, G.X. Zhang, Q.F. Zhang, Zircon U-Pb age of granitic gneiss on Duku highway in western Tianshan of China and its geological implications, Chin. Sci. Bull. 45 (7) (2000) 649-653 (in Chinese with English abstract).

[28] Y.F. Zhu, L.F. Zhang, L.B. Gu, X. Guo, J. Zhou, The zircon SHRIMP chronology and trace element geochemistry of the Carboniferous volcanic rocks in western Tianshan Mountains, Chin. Sci. Bull. 50 (19) (2005) 2201-2212 (in Chinese with English abstract).

[29] D. Zhou, S.A. Graham, E.Z. Chang, B.Y. Wang, B. Hacker, Paleozoic tectonic amalgamation of the Chinese Tianshan: Evidence from a transect along the Dushanzi-Kuqa highway, in: M.S. Hendrix, G.A. Davis (Eds.), Paleozoic and Mesozoic tectonic evolution of central Asia: from continental assembly to intracontinental deformation, Boulder, Colorado, Geol. Soc. Am. Mem. 194, 2001, pp. 23-46.

[30] L.S. Shu, W.B. Zhu, B. Wang, M. Faure, J. Charvet, D. Cluzel, The post-collision intracontinental rifting and olistostrome on the southern slope of Bogda Mountains, Xinjiang, Acta Petrol. Sin. 21(1) (2005) 25-36 (in Chinese with English abstract).

[31] L.S. Shu, B. Wang, F. Yang, H.F. Lu, J. Charvet, S. Laurent-Charvet, Polyphase Tectonic Events and Mesozoic-Cenozoic Basin-Range Coupling in the Chinese Tianshan belt, Acta Geol. Sin. 77 (4) (2003) 457-467.

[32] P. Tapponnier, P. Molnar, Active faulting and Cenozoic tectonics of the Tienshan, Mongolia and Baykal regions, J. Geophys. Res. 84 (1979) 3425-3459.

[33] J.P. Avouac, P. Tapponnier, M. Bai, H. You, G. Wang, Active thrusting and folding along 
the northern Tien Shan and Late Cenozoic rotation of the Tarim relative to Dzungaria and Kazakhstan, J. Geophys. Res. 98 (B4) (1993) 6755-6804.

[34] B.C. Burchfiel, E.T. Brown, Q.D. Deng, X.Y. Feng, J. Li, P. Molnar, J.B. Shi, Z.M. Wu, H.C. You, Crustal shortening on the Margins of the Tien Shan, Xinjiang, China, Int. Geol. Rev. 41 (1999) 665-700.

[35] J. Charreau, Y. Chen, S. Gilder, S. Dominguez, J.P. Avouac, S. Sen, D.J. Sun, Y.A. Li, W.M. Wang, Magnetostratigraphy and rock magnetism of the Neogene Kuitun He section (northwest China): implications for Late Cenozoic uplift of the Tianshan mountains, Earth Planet. Sci. Lett. 230 (1-2) (2005) 177-192.

[36] J.L. Kirschvink, The least squares line and the analysis of paleoamgnetic data, Geophys. J. R. Astron. Soc. 62 (1980) 699-718.

[37] R. Fisher, Dispersion on a sphere, Proc. R. Soc. London, Ser. A 217 (1953) 295-305.

[38] J.P. Cogné, A MacintoshTM application for treating paleomagnetic data and making plate reconstructions, Geochem. Geophys. Geosyst. 4 (1) (2003) 10.1029/2001GC000227.

[39] XBGMR (Xinjiang Bureau of Geology and Mineralogy Resources), Geological map (scale 1:200000), Zhaosu sheet (K-44-10), 1979.

[40] R.J. Enkin, The direction-correction tilt test: An all-purpose tilt/fold test for paleomagnetic studies, Earth Planet. Sci. Lett. 212 (2003) 151-166.

[41] J.D.A. Zijderveld, A.C. demagnetization of rocks: Analysis of results, in: D.W. Collinson, K.M. Creer, S.K. Runcorn (Eds.), Methods on Paleomagnetism, Elsevier, New York, 1967, pp. $245-286$.

[42] XBGMR (Xinjiang Bureau of Geology and Mineralogy Resources), Geological map 
Accepted in Earth Planetary Science Letter

(scale 1:200000), Xinyuan sheet (K-44-10), 1975.

[43] XBGMR, Geological map (scale 1:200000), Gongliu sheet (K-44-5), 1979.

[44] XBGMR, Geological map (scale 1:200000), Tuokuzi, Kumalak sheet (K-45-1), 1973.

[45] XBGMR, Geological map (scale 1:200000), Sailimuhu sheet (K-44-34), 1988.

[46] Y. Chen, J.P. Cogné, V. Courtillot, New Cretaceous paleomagnetic poles from the Tarim Basin, Northwestern China, Earth Planet. Sci. Lett. 114 (1992) 17-38.

[47] Y. Chen, V. Courtillot, J.P. Cogné, J. Besse, Z. Yang, R. Enkin, The configuration of Asia prior to the collision of India: Cretacecous paleomagnetic constraints, J. Geophys. Res. 98 (1993) $21927-21941$.

48] M.W. Hounslow, V.I. Davydov, C.T. Klootwijk, P. Turner, Magnetostratigraphy of the Carboniferous: a review and future prospects, Newsl. Carbonif. Stratigr. 22 (2004) 35-40.

[49] L.M. Bazhenov, A.Q. Collins, K.E. Degtyarev, N.M. Levashova, A.V. Mikolaichuk, V.E. Pavlov, R. Van der Voo, Paleozoic northward drift of the North Tianshan (Central Asia) as revealed by Ordovician and Carboniferous paleomagmatism, Tectonophysics 366 (2003) $113-141$.

[50] G.L. Cheng, Y.H. Bai, Y.A. Li, Paleomagnetism of Lower Permian in the Wushi-Aksu area of Xinjiang, Seismology and Geology 5 (4) (1983) 12 (In Chinese).

[51] Y.H. Bai, G.L. Cheng, Q.G. Sun, Y.H. Sun, Y.G. Li, Y.J. Dong, D.J. Sun, Late Paleozoic polar wander path for the Tarim platform and its tectonic significance, Tectonophysics 139 (1987) 145-153.

[52] Y.P. Li, M. McWilliams, A. Cox, R. Sharps, Y.A. Li, Z.J. Gao, Z.K. Zhang, Y.J. Zhai, Late Permian paleomagnetic pole from dikes of the Tarim craton, China, Geology 16 (1988) 
$275-278$.

[53] P.L. McFadden, X.H. Ma, M.W. McElhinny, Z.K. Zhang, Permo-Triassic magnetostratigraphy in China: northern Tarim, Earth Planet. Sci. Lett. 87 (1988) 152-160.

[54] Y.J. Zhai, Z.K. Zhang, Y.P. Li, Q. Li, Y. Li, M. McWilliams, A. Cox, R. Sharps, A study of Upper Carboniferous paleomagnetism for the Tarim block, Geoscience 2 (1988) 43-56.

[55] Z. Meng, J. Zheng, Palaeomagnetic investigations of the Apparent Polar Wander path of Tarim and relative motions between sub-tectonic units, in: Q. Zhou, J. Zheng (Eds.), Tectonic Synthetis of Tarim, Science Press, Beijing, 1990, pp. 50-87 (in Chinese with English abstract).

[56] D.J. Fang, H.L. Chen, G.H. Jin, Y.B. Guo, Z.L. Wang, X.D. Tan, S.H. Yin, Late Paleozoic and Mesozoic paleomagnetism and tectonic evolution of Tarim terrane, in: T.J. Wiley, D.G. Howell, F.L. Wong (Eds.), Terrane analysis of China and the Pacific rim, Houston (USA), Circum-Pacific Council for Energy and Mineral Resources, Earth Science Series 13, 1990, pp. 251-255.

[57] D.J. Fang, G.H. Jin, L.P. Jiang, P.Y. Wang, Z.L. Wang, Paleozoic paleomagnetic results from Tarim basin and their tectonic implication, Acta Geophys. Sin. 39 (4) (1996) 522-531 (in Chinese).

[58] Z. Meng, Palaeomagnetic study of Upper Palaeozoic erathem along the southwestern margin of Tarim block, China, Acta Sedimentol. Sin. 9 (1991) 105-109 (in Chinese with English abstract).

[59] S. Gilder, X.X. Zhao, R.S. Coe, Z. Meng, V. Courtillot, J. Besse, Paleomagnetism and tectonics of the southern Tarim basin, northwestern China, J. Geophys. Res. 101 (1996) 22 
015-22 031.

[60] R. Van der Voo, Paleomagnetism of the Atlantic, Tethys and Iapetus Oceans, Cambridge University Press, Cambridge, 1993.

[61] Y.P. Li, R. Sharps, M. McWilliams, A. Nur, Y.G. Li, Q. Li, and W. Zhang, Paleomagnetic results from Late Paleozoic dikes from the northwestern Junggar block, Northwestern China, Earth Planet. Sci. Lett., 94 (1989) 123-130.

[62] Y.P. Li, R. Sharps, M. McWilliams, Y.G. Li, Q. Li, W. Zhang, Late Paleozoic Paleomagnetic results from the Junggar block, Northwestern China, J. Geophys. Res. 96 (1991) $16047-16060$.

[63] R. Sharps, Y.P. Li, M. McWilliams, Y.G. Li, Paleomagnetic investigation of Upper Permian sediments in the South Junggar Basin, China, J. Geophys. Res. 97 (1992) 1753-1765.

[64] S.Y. Nie, D.B. Rowley, R. Van der Voo, M.S. Li, Paleomagnetism of Late Paleozoic rocks in the Tianshan, Northwestern China, Tectonics 12 (1993) 568-579.

[65] J.M. Zhao, G.D. Liu, Z.X. Lu, X.K. Zhang, G.Z. Zhao, Lithospheric structure and dynamic processes of the Tianshan orogenic belt and the Junggar basin, Tectonophysics 376 (2003) 199-239.

[66] F. Harkand, J.P. Cogné, V. Kravchinsky, A new Late Cretaceous paleomagnetic pole for the west of Amuria block (Khurmen Uul, Mongolia), Earth Planet. Sci. Lett. 236 (2005) $359-373$. 
Figure and Table captions:

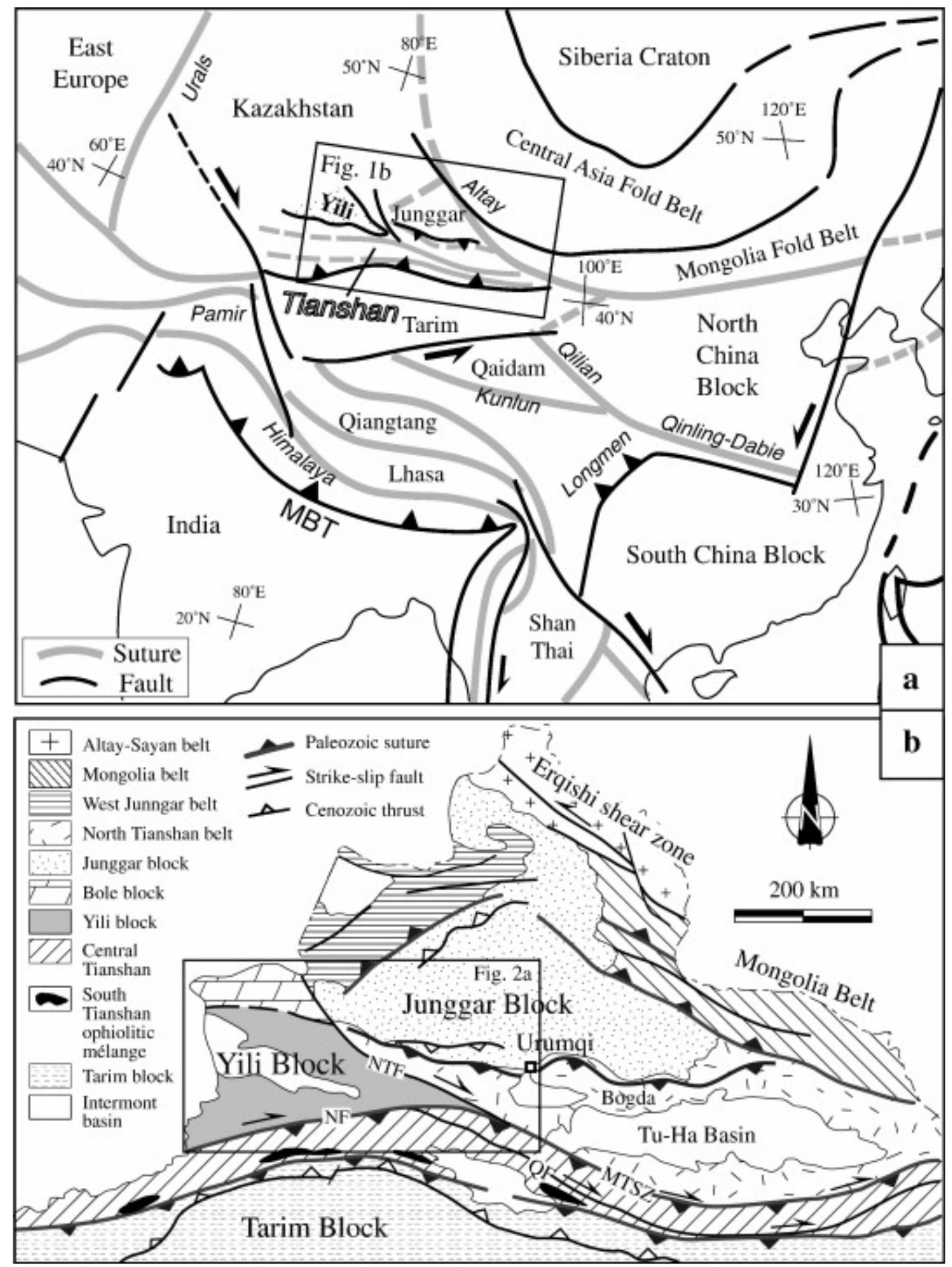

Figure 1. (a) Tectonic sketch map of Central Asia (modified after [1]) showing the main tectonic blocks including the Yili Block, (b) structural map of Chinese Tianshan Belt and its adjacent areas. Paleozoic sutures, Permian strike-slip faults and Cenozoic thrusts are shown. Abbreviations: NTF, North Tianshan Fault; NF, Nalati Fault; MTSZ, Main Tianshan Shear Zone; QF, Qingbulake Fault. 


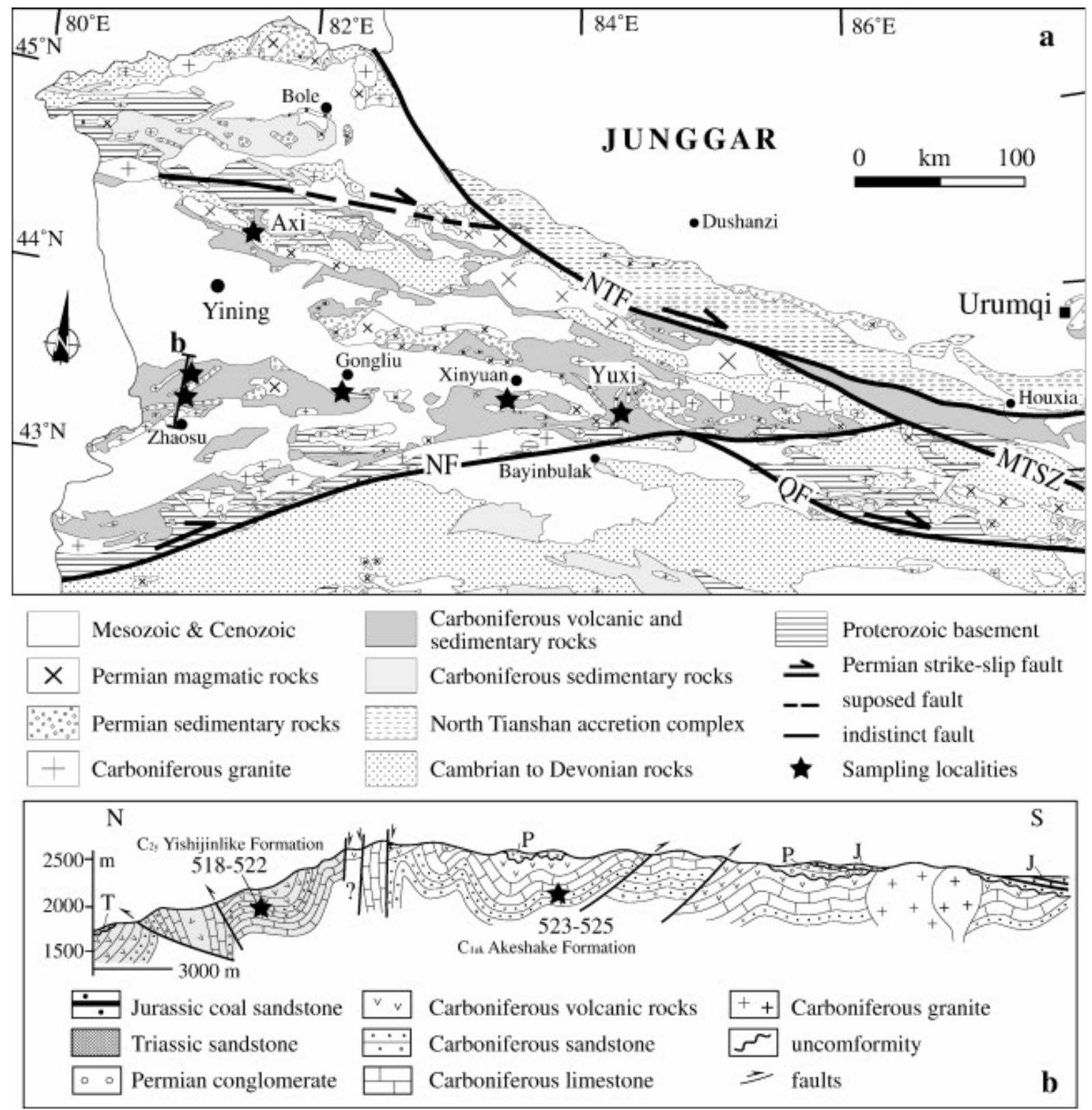

Figure 2. (a) Geological map of the Yili Block and adjacent areas indicating the sampling localities, (b) simplified cross section of Zhaosu area. 

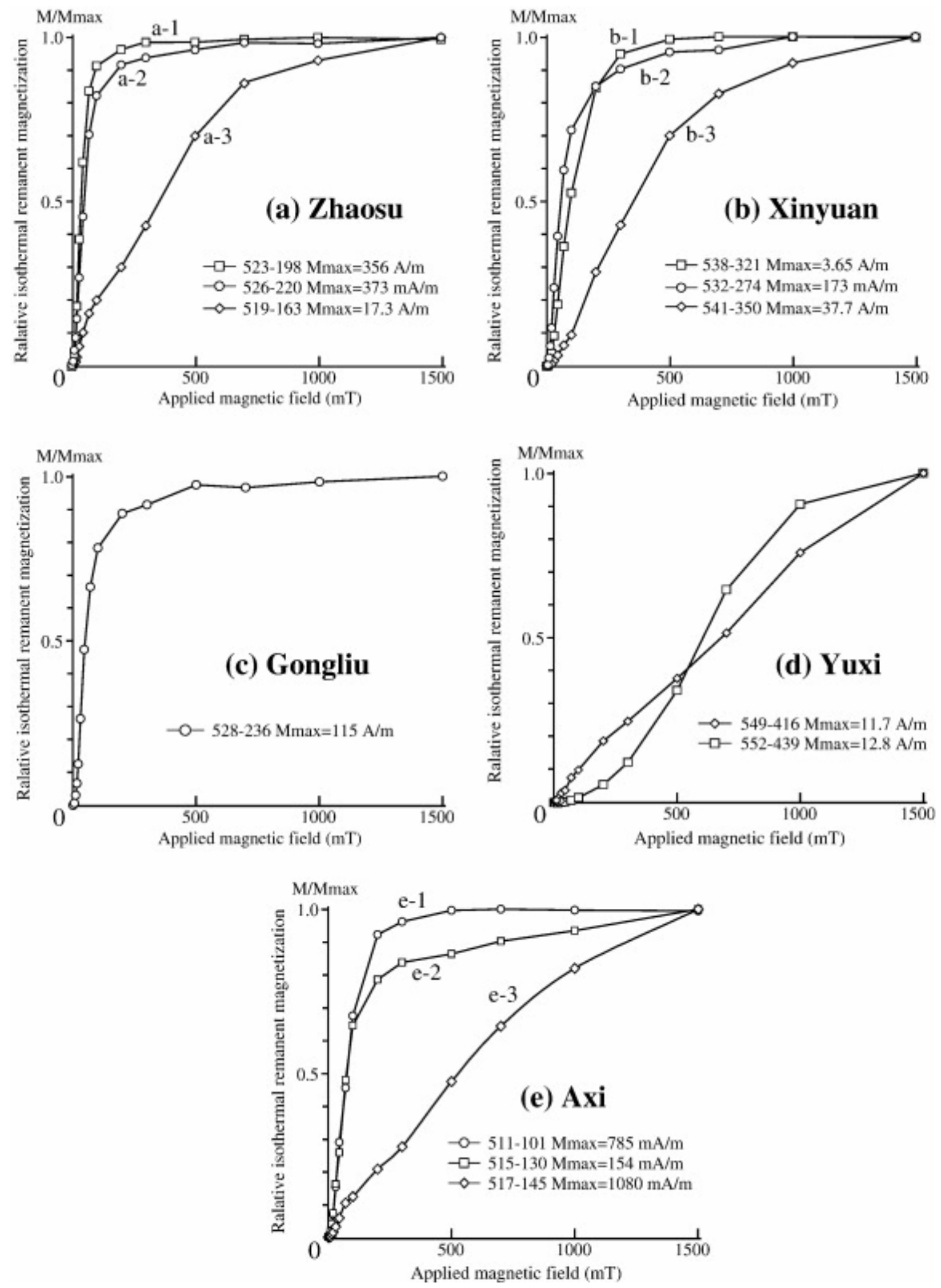

Figure 3. Isothermal magnetization results of representative cores from each sampled locality. 

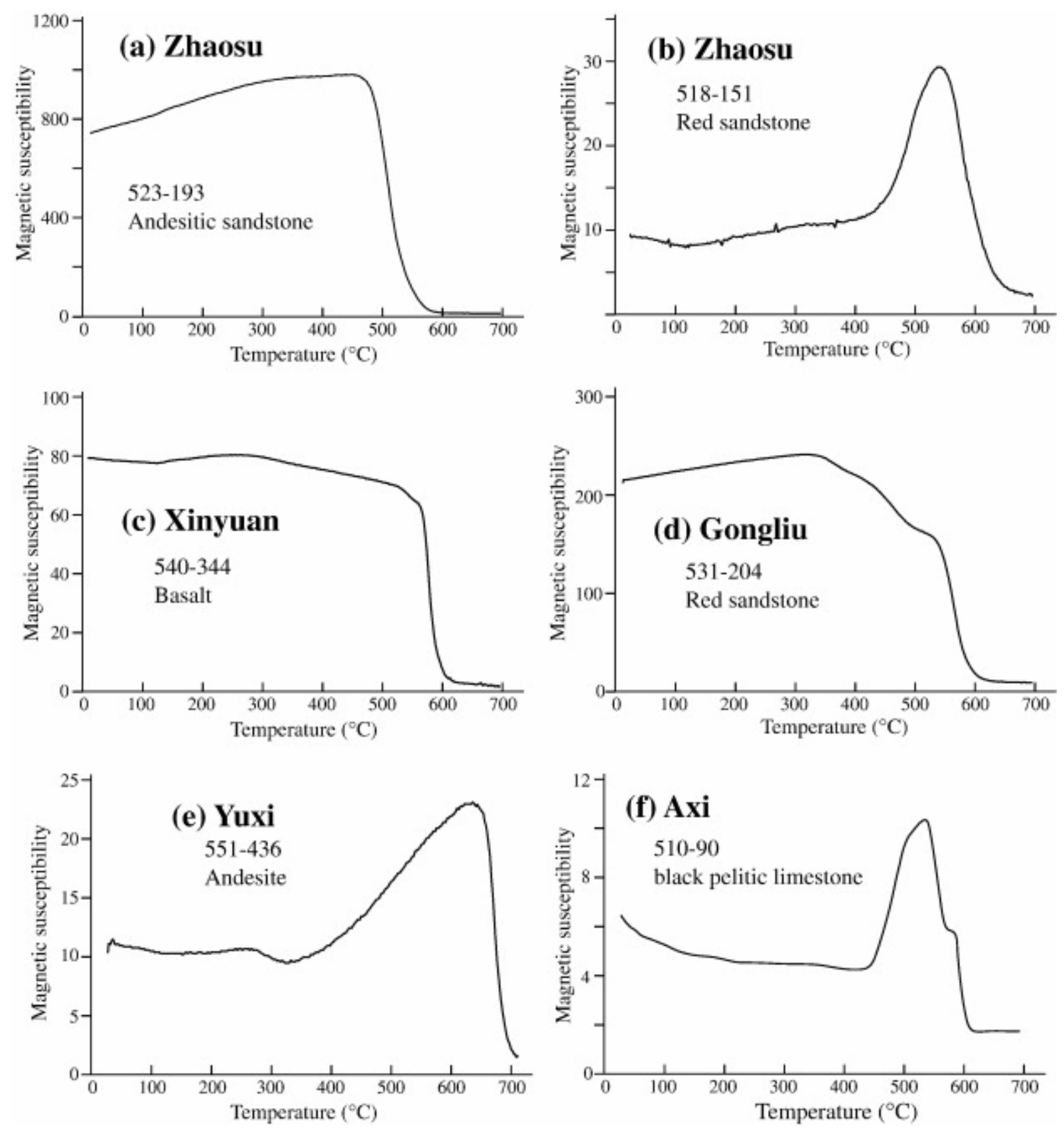

Figure 4. Results of thermomagnetic Curie temperature analyses on representative lithologies of the Yili Block. 

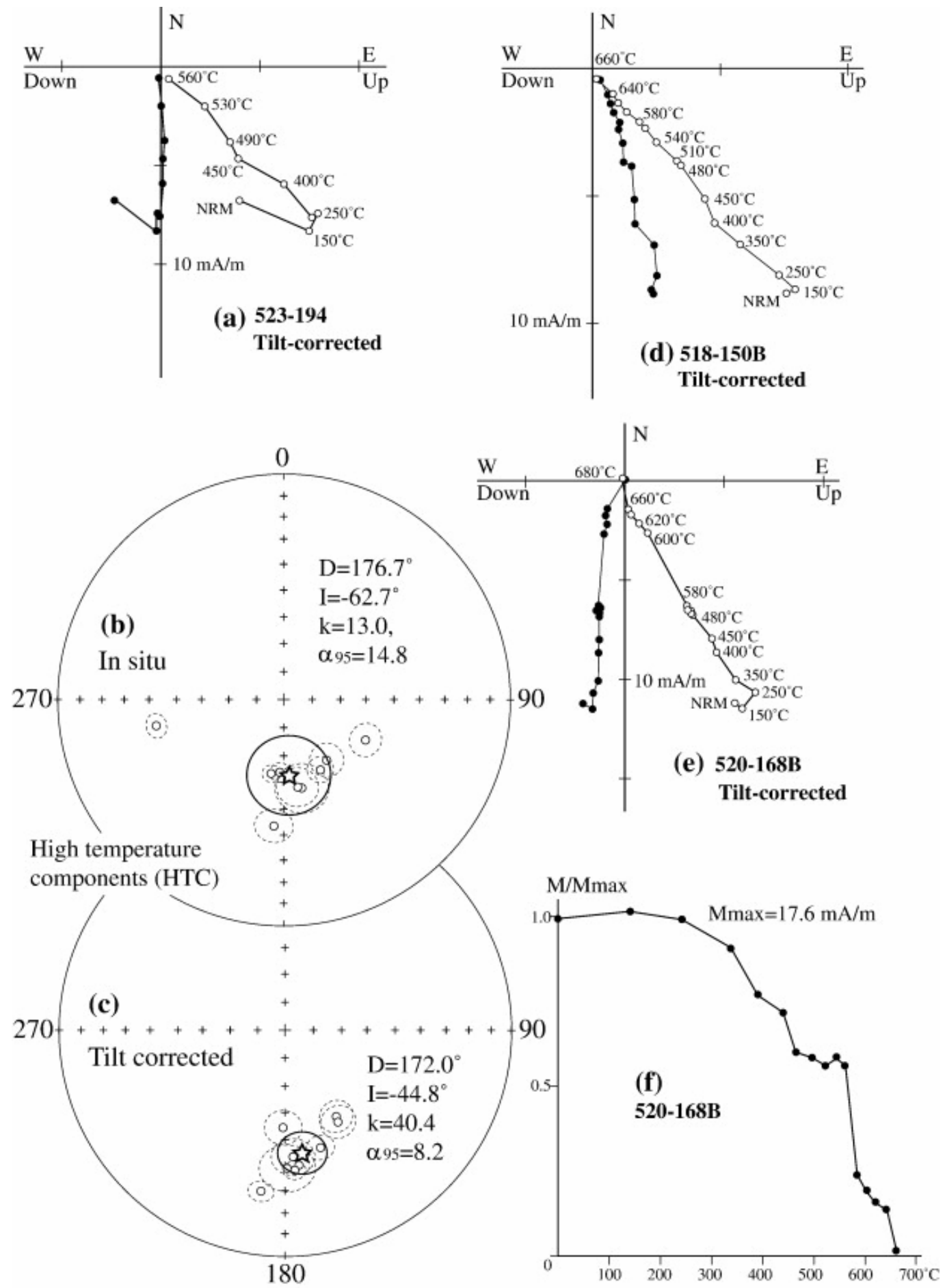

Figure 5. Measurement results from Zhaosu area. (a-c) Orthogonal projection of sample demagnetization (Zijderveld [41]) in stratigraphic coordinates and (d) normalized intensity curves of progressive demagnetization. White (black) circles represent vertical (horizontal) plans. (e) and (f) equal-area stereoplots for site-mean directions isolated from high temperature components in geographic and stratigraphic coordinates, respectively. Stars represent the locality-mean directions. 

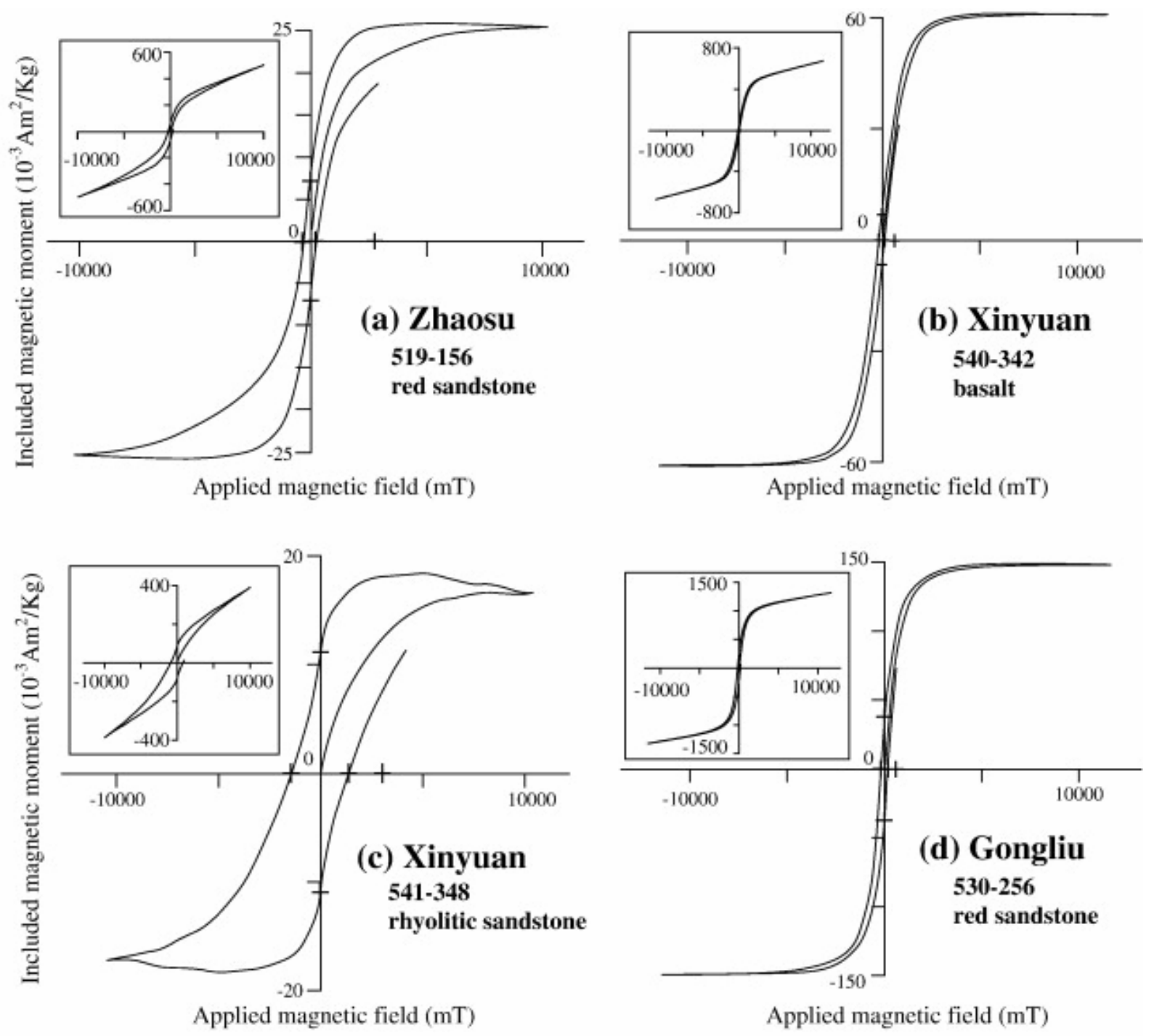

Figure 6. Representative hysteresis loops of samples from the Yili Block 

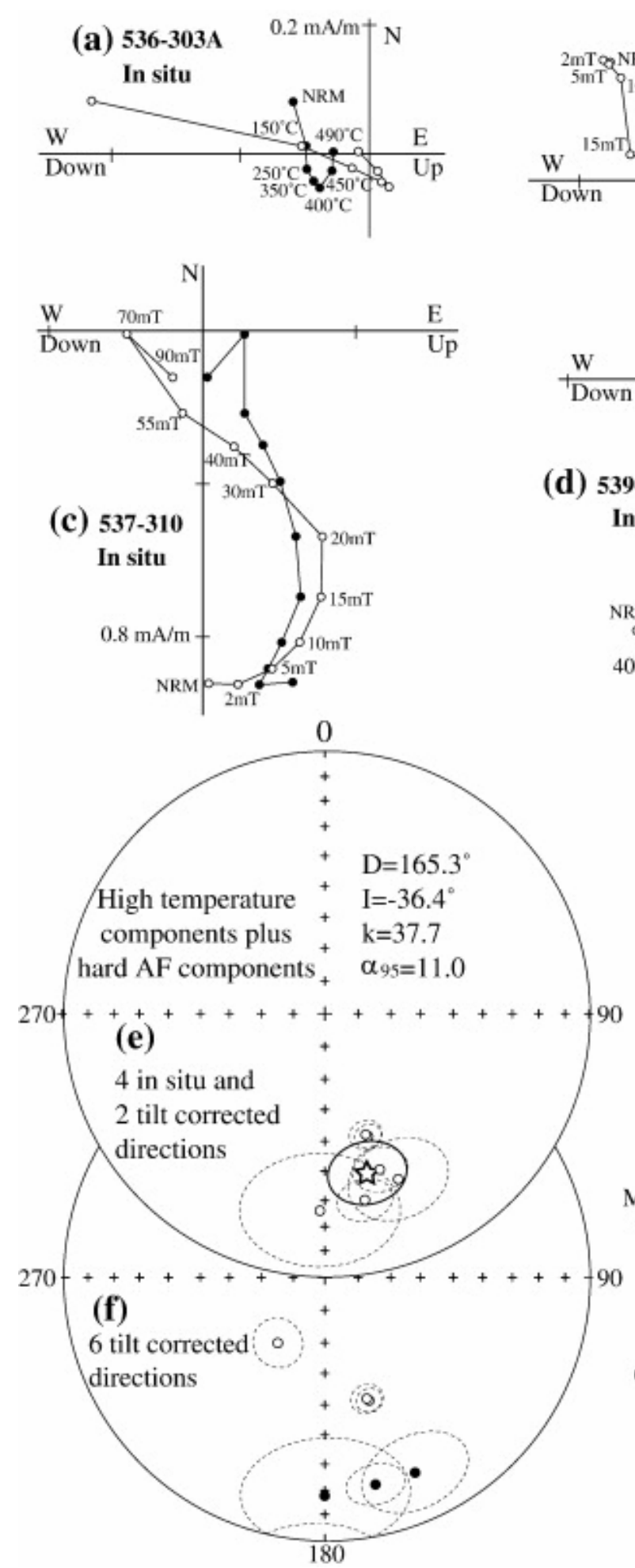
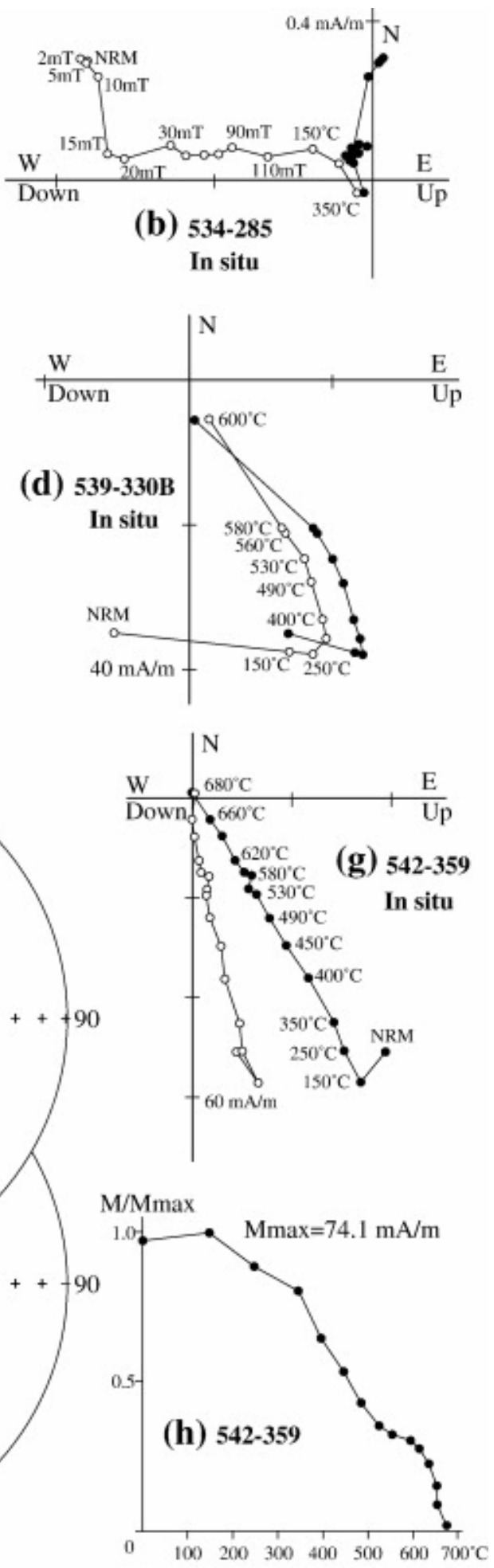

Figure 7. Measurement results from Xinyuan area. (a-d) and (g) Orthogonal projection in geographic coordinates and (h) normalized intensity curves of progressive demagnetization. (e) and (f) equal-area stereoplots for high temperature and hard AF components. White (black) circles in (e) and (f) represent reversal (normal) polarities of site-mean direction, other symbols are same as in Fig. 5. 

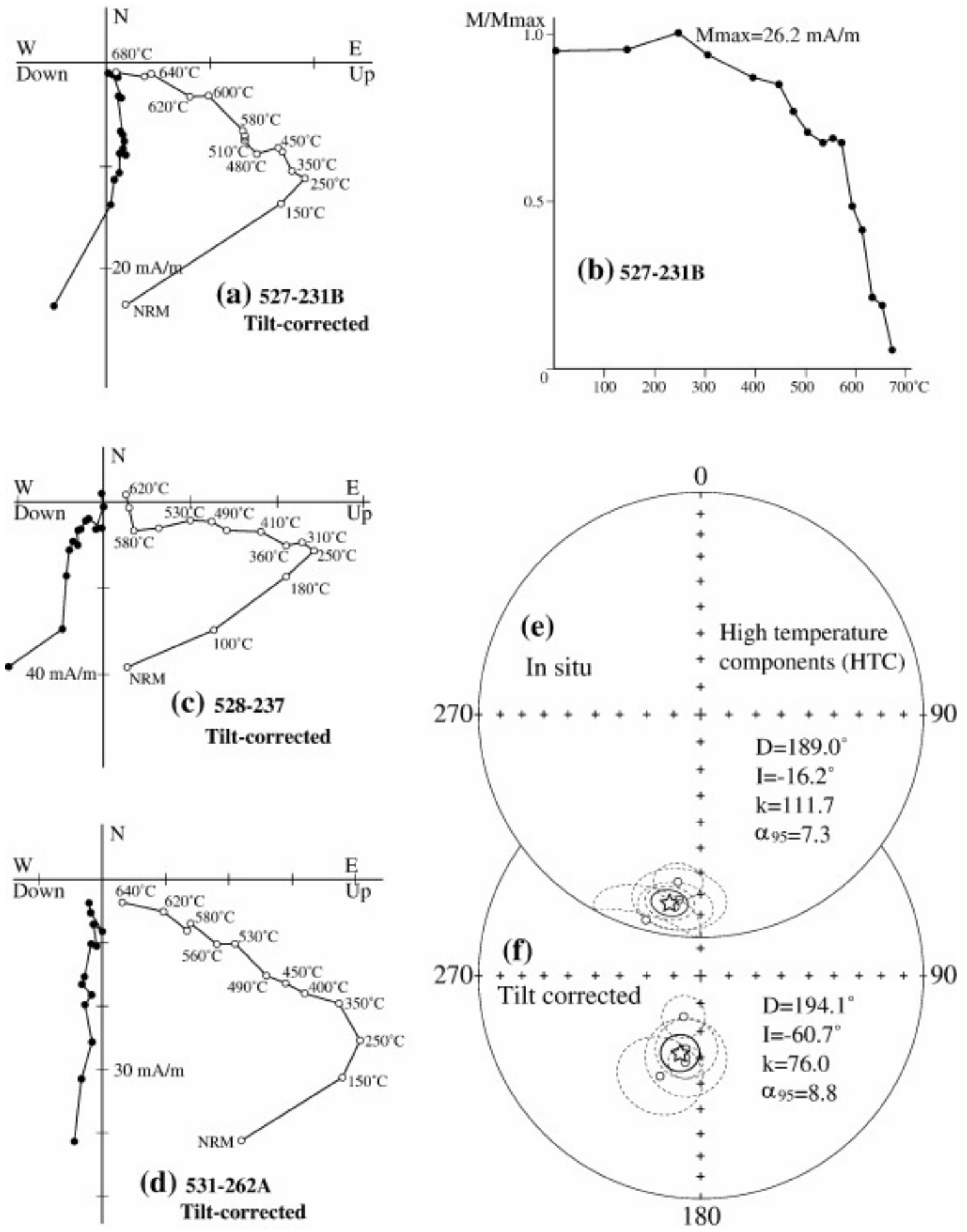

Figure 8. Measurement results from Gongliu area. (a) and (c-d) Orthogonal projection in stratigraphic coordinates and (b) normalized intensity curves of progressive demagnetization. (e) and (f) equal-area stereoplot for high temperature components in geographic and stratigraphic coordinates, respectively. Symbols are same as in Fig. 5 


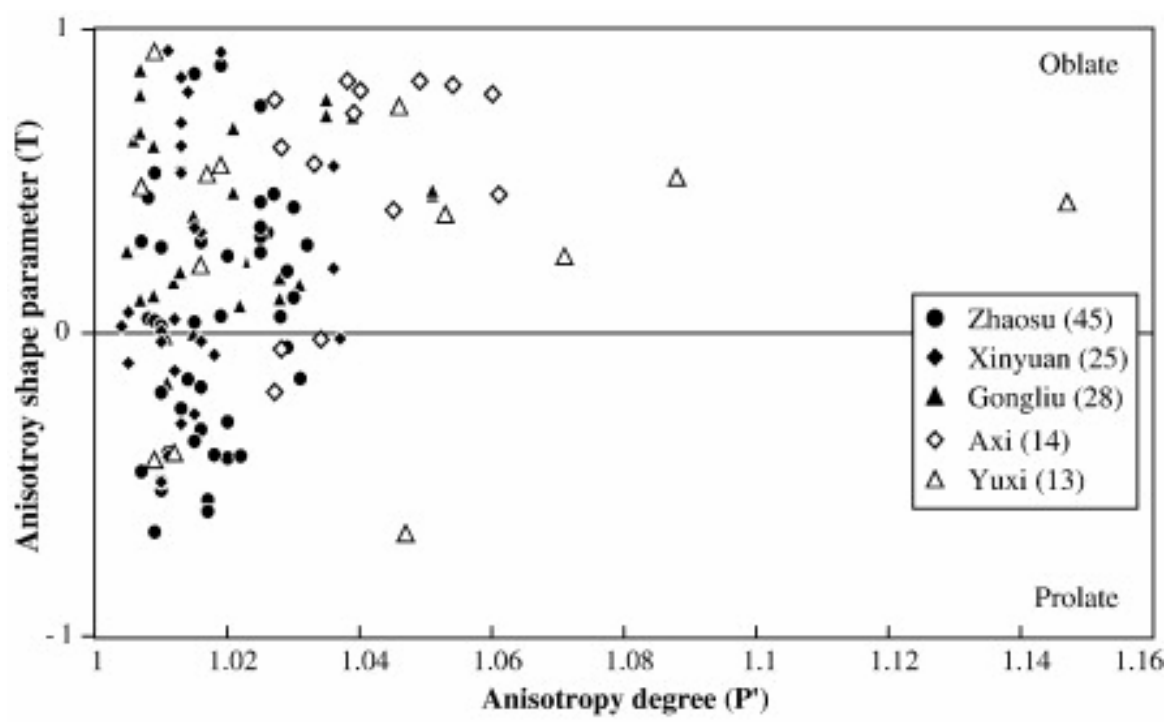

Figure 9. Plots of anisotropy degree $\left(P^{\prime}\right)$ versus anisotropy shape $(T)$ of magnetic susceptibility for volcanic and sedimentary rocks in the Yili Block and its adjacent areas. $P^{\prime}=$ $\exp \left\{2\left[(\ln K 1-\ln K m)^{2}+(\ln K 2-\ln K m)^{2}+(\ln K 3-\ln K m)^{2}\right]^{1 / 2}\right\}$, and $T=2 \ln (K 2 / K 3) / \ln (K 1 / K 3)-1$, where $K 1, K 2$ and $K 3$ are principal axes of the magnetic fabrics and $K \mathrm{~m}$ is their average. 

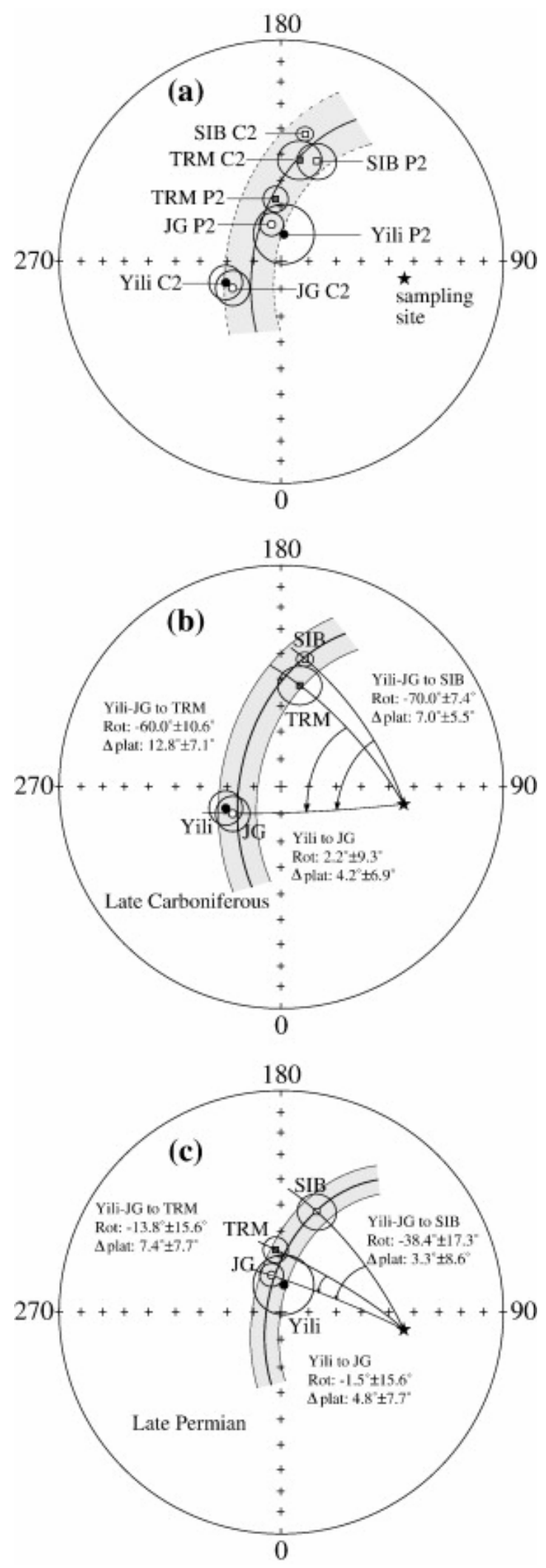

Figure 10. (a) Equal-area projections of Late Carboniferous and Late Permian poles of Yili Block, Tarim (TRM), Junggar (JG) and Siberia (SIB), showing that little or no relative latitudinal movement among these blocks, (b) small circle passing through Late Carboniferous poles and grand circles from sampling site 
Accepted in Earth Planetary Science Letter

to each pole showing significant longitudinal differences between different blocks, (c) no significant longitudinal differences between Yili, Junggar and Tarim shown by small circles passing through Late Permian pole, but a significant longitudinal difference exited between Siberia and the other blocks at Late Permian time. Rot and $\Delta$ plat stand for relative rotation and convergence with corresponding uncertainties. The positive mean value stands for clockwise rotation and latitudinal shortening, respectively. 

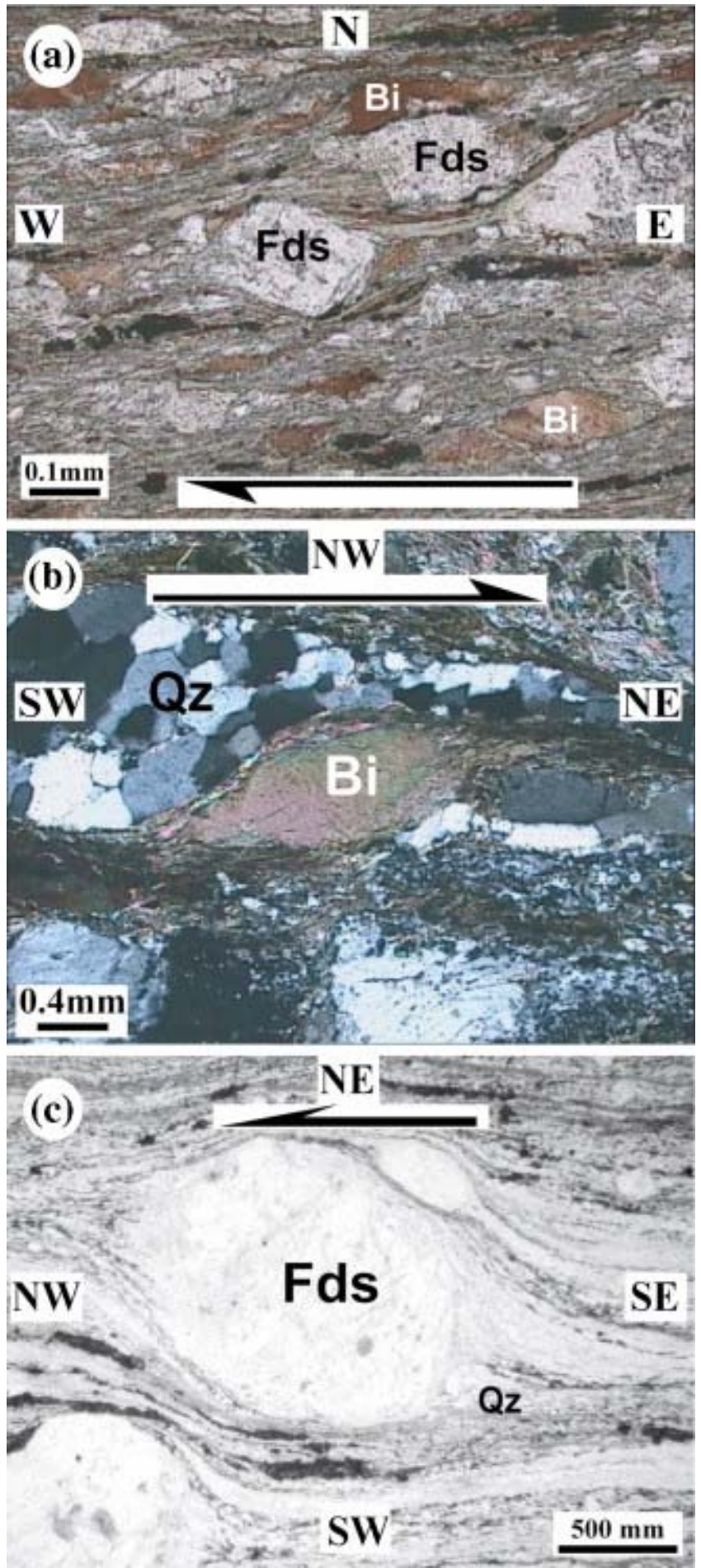

Figure 11. Microscopic kinematic indicators from ductile strike-slip shear zones, (a) feldspar clasts with biotite pressure shadow showing dextral signature of the North Tianshan shear zone; (b) mica-fish and oblique quartz sub-grain textures indicating dextral shearing along the Nalati Fault; (c) sigmoidal feldspar clast with pressure shadows of quartz and biotite showing sinistral movement of the Erqishi shear zone in the Altay Belt. 

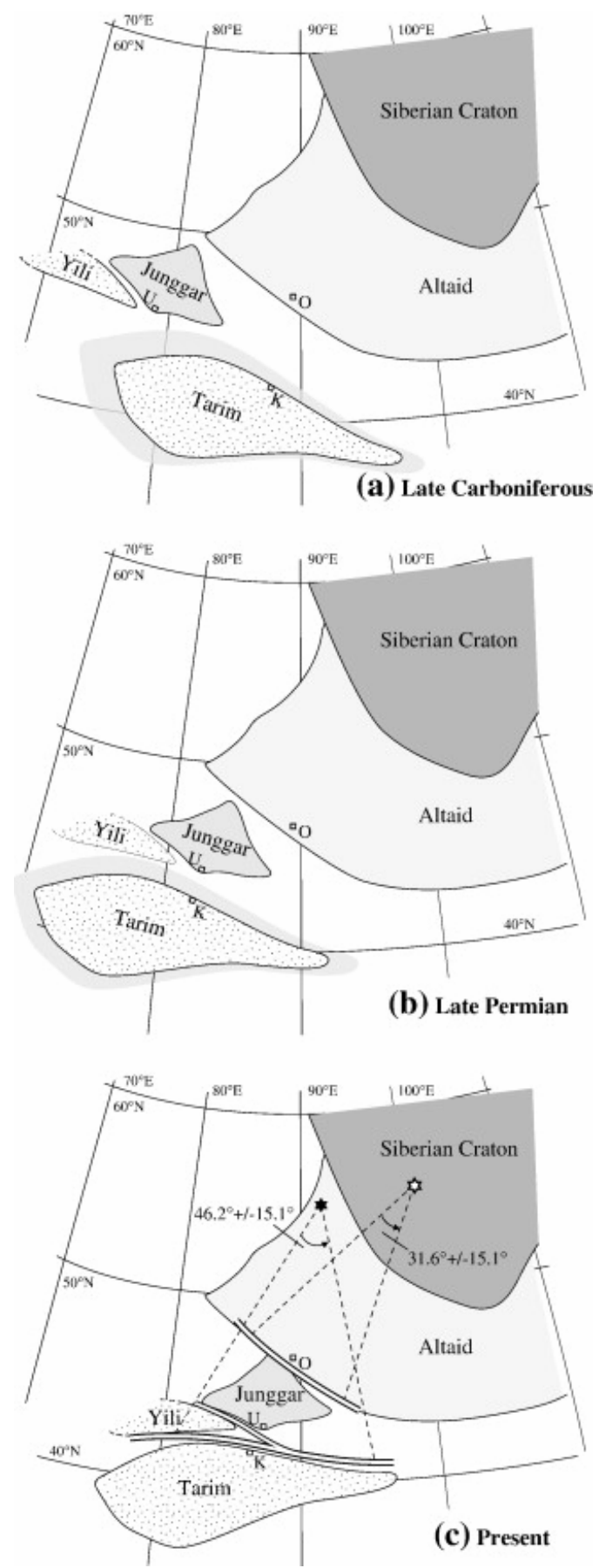

Figure 12. Simplified reconstruction maps showing the relative rotations of major blocks and consequent lateral displacements along their boundaries by fixing Siberia at its present position. Late Carboniferous (a), Late Permain (b) and Present (c) states are compared. Shadowed zones around the Tarim indicate the subducted margins of Tarim during Cenozoic intra-continental deformation. K, U and O stand for Korla, Urumqi and Ölgij (Mongolian). 
Accepted in Earth Planetary Science Letter

Table 1. Paleomagnetic sampling and measurement results from the Yili Block

\begin{tabular}{|c|c|c|c|c|c|c|c|c|c|c|c|c|}
\hline Site & Coordinates & Rocks & Age & Strike/dip & $n / N^{\mathrm{a}}$ & $P$ & Dg & Ig & Ds & Is & $k$ & $\alpha_{95}$ \\
\hline \multicolumn{13}{|c|}{ Zhaosu area } \\
\hline 523 & $\begin{array}{l}43.3^{\circ} \mathrm{N} \\
81.0^{\circ} \mathrm{E}\end{array}$ & $\begin{array}{l}\text { Andesitic } \\
\text { sandstone }\end{array}$ & $\mathrm{C}_{1} \mathrm{ak}\left(\mathrm{C}_{2}\right)^{\mathrm{b}}$ & $110 / 12$ & $6 / 8$ & $\mathrm{R}$ & 185.1 & -43.5 & 181.1 & -55.0 & 140.7 & 6.5 \\
\hline 524 & $\begin{array}{l}43.3^{\circ} \mathrm{N} \\
81.0^{\circ} \mathrm{E}\end{array}$ & $\begin{array}{l}\text { Red } \\
\text { sandstone }\end{array}$ & $\mathrm{C}_{1} \mathrm{ak}\left(\mathrm{C}_{2}\right)$ & $245 / 25$ & $6 / 8$ & $\mathrm{R}$ & 190.4 & -63.0 & 174.0 & -40.3 & 354.9 & 3.2 \\
\hline 525 & $\begin{array}{l}43.3^{\circ} \mathrm{N} \\
81.0^{\circ} \mathrm{E}\end{array}$ & Sandstone & $\mathrm{C}_{1} \mathrm{ak}\left(\mathrm{C}_{2}\right)$ & $255 / 26$ & $6 / 9$ & $\mathrm{R}$ & 184.0 & -63.7 & 176.1 & -38.4 & 324.7 & 3.7 \\
\hline 526 & $\begin{array}{l}43.3^{\circ} \mathrm{N} \\
81.6^{\circ} \mathrm{E}\end{array}$ & $\begin{array}{l}\text { Yellow } \\
\text { sandstone }\end{array}$ & $\mathrm{C}_{1} \mathrm{ak}\left(\mathrm{C}_{2}\right)$ & $230 / 78$ & $7 / 10$ & $\mathrm{R}$ & 258.6 & -41.8 & 188.6 & -29.2 & 220.0 & 4.1 \\
\hline \multirow[t]{2}{*}{ Mean } & & & & & 4 & $\mathrm{R}$ & 207.3 & -57.8 & & & 10.5 & 29.8 \\
\hline & & & & & & & & & 180.2 & -40.9 & 46.9 & 13.6 \\
\hline 518 & $\begin{array}{l}43.5^{\circ} \mathrm{N} \\
81.1^{\circ} \mathrm{E}\end{array}$ & $\begin{array}{l}\text { Red } \\
\text { sandstone }\end{array}$ & $\mathrm{C}_{2 \mathrm{y}}$ & $270 / 18$ & $6 / 8$ & $\mathrm{R}$ & 153.1 & -61.8 & 163.1 & -45.3 & 197.6 & 4.8 \\
\hline 519 & $\begin{array}{l}43.5^{\circ} \mathrm{N} \\
81.1^{\circ} \mathrm{E}\end{array}$ & $\begin{array}{l}\text { Red } \\
\text { sandstone }\end{array}$ & $\mathrm{C}_{2 \mathrm{y}}$ & $305 / 22$ & $6 / 8$ & $\mathrm{R}$ & 116.3 & -57.5 & 149.0 & -54.0 & 66.7 & 6.0 \\
\hline 520 & $\begin{array}{l}43.4^{\circ} \mathrm{N} \\
81.1^{\circ} \mathrm{E}\end{array}$ & Sandstone & $\mathrm{C}_{2 \mathrm{y}}$ & $270 / 20$ & $6 / 10$ & $\mathrm{R}$ & 169.1 & -57.2 & 179.0 & -39.1 & 43.1 & 9.3 \\
\hline 521 & $\begin{array}{l}43.4^{\circ} \mathrm{N} \\
81.1^{\circ} \mathrm{E}\end{array}$ & Sandstone & $\mathrm{C}_{2 \mathrm{y}}$ & $280 / 15$ & $6 / 8$ & $\mathrm{R}$ & 171.6 & -57.9 & 176.4 & -43.4 & 84.4 & 7.3 \\
\hline 522 & $\begin{array}{l}43.4^{\circ} \mathrm{N} \\
81.1^{\circ} \mathrm{E}\end{array}$ & Sandstone & $\mathrm{C}_{2 \mathrm{y}}$ & $250 / 12$ & $6 / 9$ & $\mathrm{R}$ & 145.7 & -63.5 & 149.7 & -51.8 & 80.4 & 6.2 \\
\hline \multirow[t]{2}{*}{ Mean } & & & & & 5 & $\mathrm{R}$ & 151.6 & -61.2 & & & 48.0 & 11.2 \\
\hline & & & & & & & & & 164.7 & -47.4 & 50.7 & 10.9 \\
\hline \multicolumn{13}{|c|}{ Xinyuan area } \\
\hline 532 & $\begin{array}{l}43.3^{\circ} \mathrm{N} \\
83.3^{\circ} \mathrm{E}\end{array}$ & $\begin{array}{l}\text { Tuffaceous } \\
\text { sandstone }\end{array}$ & $\mathrm{C}_{1}$ aw & $287 / 48$ & $9 / 9$ & - & - & - & - & - & - & - \\
\hline 533 & $\begin{array}{l}43.3^{\circ} \mathrm{N} \\
83.3^{\circ} \mathrm{E}\end{array}$ & $\begin{array}{l}\text { Tuffaceous } \\
\text { sandstone }\end{array}$ & $\mathrm{C}_{1} \mathrm{aw}$ & $285 / 51$ & $8 / 8$ & - & - & - & - & - & - & - \\
\hline 534 & $\begin{array}{l}43.3^{\circ} \mathrm{N} \\
83.3^{\circ} \mathrm{E}\end{array}$ & $\begin{array}{l}\text { Tuffaceous } \\
\text { sandstone }\end{array}$ & $\mathrm{C}_{1}$ aw & $292 / 52$ & $8 / 9$ & - & - & - & - & - & - & - \\
\hline 535 & $\begin{array}{l}43.3^{\circ} \mathrm{N} \\
83.3^{\circ} \mathrm{E}\end{array}$ & $\begin{array}{l}\text { Tuffaceous } \\
\text { sandstone }\end{array}$ & $\mathrm{C}_{1}$ aw & $268 / 45$ & $8 / 8$ & - & - & - & - & - & - & - \\
\hline 536 & $\begin{array}{l}43.3^{\circ} \mathrm{N} \\
83.3^{\circ} \mathrm{E}\end{array}$ & $\begin{array}{l}\text { Tuffaceous } \\
\text { sandstone }\end{array}$ & $\mathrm{C}_{1}$ aw & $272 / 48$ & $9 / 9$ & - & - & - & - & - & - & - \\
\hline
\end{tabular}


Accepted in Earth Planetary Science Letter

\begin{tabular}{|c|c|c|c|c|c|c|c|c|c|c|c|c|}
\hline Site & Coordinates & Rocks & Age & Strike/dip & $n / N^{\mathrm{a}}$ & $P$ & Dg & Ig & Ds & Is & $k$ & $\alpha_{95}$ \\
\hline 537 & $\begin{array}{l}43.3^{\circ} \mathrm{N} \\
83.3^{\circ} \mathrm{E}\end{array}$ & Basalt & $\mathrm{C}_{1}$ aw $\left(\mathrm{C}_{2}\right)$ & $240 / 47$ & $7 / 9$ & $\mathrm{R}$ & 181.5 & -24.0 & 179.9 & 16.9 & 6.1 & 21.2 \\
\hline 538 & $\begin{array}{l}43.3^{\circ} \mathrm{N} \\
83.3^{\circ} \mathrm{E}\end{array}$ & $\begin{array}{l}\text { Basaltic } \\
\text { tuff }\end{array}$ & $\mathrm{C}_{1} \mathrm{aw}\left(\mathrm{C}_{2}\right)$ & $237 / 49$ & $8 / 8$ & $\mathrm{R}$ & 167.9 & -27.4 & 166.6 & 18.9 & 35.9 & 7.7 \\
\hline 539 & $\begin{array}{l}43.3^{\circ} \mathrm{N} \\
83.3^{\circ} \mathrm{E}\end{array}$ & Basalt & $\mathrm{C}_{1} \mathrm{aw}\left(\mathrm{C}_{2}\right)$ & $237 / 49$ & $8 / 8$ & $\mathrm{R}$ & 156.2 & -30.5 & 155.4 & 18.0 & 11.2 & 14.3 \\
\hline 540 & $\begin{array}{l}43.3^{\circ} \mathrm{N} \\
83.3^{\circ} \mathrm{E}\end{array}$ & Basalt & $\mathrm{C}_{1} \mathrm{aw}\left(\mathrm{C}_{2}\right)$ & $237 / 49$ & $8 / 12$ & $\mathrm{R}$ & 160.5 & -36.6 & 216.7 & -64.4 & 35.0 & 7.8 \\
\hline 541 & $\begin{array}{l}43.4^{\circ} \mathrm{N} \\
83.3^{\circ} \mathrm{E}\end{array}$ & $\begin{array}{l}\text { Rhyolitic } \\
\text { sandstone }\end{array}$ & $\mathrm{C}_{1} \mathrm{aw}\left(\mathrm{C}_{2}\right)$ & $38 / 48$ & $6 / 7$ & $\mathrm{R}$ & 149.0 & -5.2 & 160.8 & -48.7 & 289.7 & 3.9 \\
\hline 542 & $\begin{array}{l}43.4^{\circ} \mathrm{N} \\
83.3^{\circ} \mathrm{E}\end{array}$ & $\begin{array}{l}\text { Rhyolitic } \\
\text { sandstone }\end{array}$ & $\mathrm{C}_{1} \mathrm{aw}\left(\mathrm{C}_{2}\right)$ & $29 / 47$ & $6 / 7$ & $\mathrm{R}$ & 145.5 & -9.5 & 161.5 & -49.2 & 187.6 & 4.9 \\
\hline $\operatorname{Mean}^{\mathrm{c}}$ & & & & & 6 & $\mathrm{R}$ & & & 165.3 & -36.4 & 37.7 & 11.0 \\
\hline \multicolumn{13}{|c|}{ Gongliu area } \\
\hline 527 & $\begin{array}{l}43.4^{\circ} \mathrm{N} \\
82.5^{\circ} \mathrm{E}\end{array}$ & $\begin{array}{l}\text { Red } \\
\text { sandstone }\end{array}$ & $\mathrm{P}_{2} \mathrm{x}$ & $93 / 40$ & $6 / 8$ & $\mathrm{R}$ & 186.5 & -17.7 & 189.5 & -59.3 & 11.0 & 14.1 \\
\hline 528 & $\begin{array}{l}43.4^{\circ} \mathrm{N} \\
82.5^{\circ} \mathrm{E}\end{array}$ & $\begin{array}{l}\text { Red } \\
\text { sandstone }\end{array}$ & $\mathrm{P}_{2} \mathrm{x}$ & $93 / 45$ & $6 / 8$ & $\mathrm{R}$ & 194.9 & -6.2 & 201.6 & -49.8 & 8.7 & 14.9 \\
\hline 529 & $\begin{array}{l}43.4^{\circ} \mathrm{N} \\
82.5^{\circ} \mathrm{E}\end{array}$ & $\begin{array}{l}\text { Red } \\
\text { sandstone }\end{array}$ & $\mathrm{P}_{2} \mathrm{x}$ & $95 / 48$ & $6 / 7$ & $\mathrm{R}$ & 187.5 & -14.6 & 190.3 & -62.5 & 38.7 & 10.9 \\
\hline 530 & $\begin{array}{l}43.4^{\circ} \mathrm{N} \\
82.5^{\circ} \mathrm{E}\end{array}$ & $\begin{array}{l}\text { Red } \\
\text { sandstone }\end{array}$ & $\mathrm{P}_{2} \mathrm{x}$ & $92 / 49$ & $6 / 8$ & $\mathrm{R}$ & 187.7 & -25.6 & 200.9 & -73.9 & 74.3 & 7.8 \\
\hline 531 & $\begin{array}{l}43.4^{\circ} \mathrm{N} \\
82.5^{\circ} \mathrm{E}\end{array}$ & $\begin{array}{l}\text { Red } \\
\text { sandstone }\end{array}$ & $\mathrm{P}_{2} \mathrm{x}$ & $100 / 41$ & $6 / 9$ & $\mathrm{R}$ & 189.4 & -16.6 & 189.4 & -57.6 & 123.4 & 5.8 \\
\hline \multirow[t]{2}{*}{ Mean } & & & & & 5 & $\mathrm{R}$ & 189.3 & -16.2 & & & 111.7 & 7.3 \\
\hline & & & & & & & & & 194.1 & -60.7 & 76.1 & 8.8 \\
\hline \multicolumn{13}{|c|}{ Yuxi area } \\
\hline 549 & $\begin{array}{l}43.4^{\circ} \mathrm{N} \\
84.4^{\circ} \mathrm{E}\end{array}$ & Andesite & $\mathrm{C}_{2} \mathrm{t}$ & $54 / 15$ & $6 / 7$ & $\mathrm{R}$ & 214.4 & -35.7 & 225.7 & -39.3 & 380.6 & 3.4 \\
\hline 550 & $\begin{array}{l}43.4^{\circ} \mathrm{N} \\
84.4^{\circ} \mathrm{E}\end{array}$ & Andesite & $\mathrm{C}_{2} \mathrm{t}$ & $54 / 15$ & $6 / 7$ & $\mathrm{R}$ & 212.0 & -35.3 & 223.1 & -39.6 & 411.8 & 3.3 \\
\hline 551 & $\begin{array}{l}43.4^{\circ} \mathrm{N} \\
84.4^{\circ} \mathrm{E}\end{array}$ & Andesite & $\mathrm{C}_{2} \mathrm{t}$ & $54 / 15$ & $6 / 7$ & $\mathrm{R}$ & 213.0 & -37.5 & 225.1 & -41.4 & 64.7 & 8.4 \\
\hline 552 & $\begin{array}{l}43.4^{\circ} \mathrm{N} \\
84.4^{\circ} \mathrm{E}\end{array}$ & $\begin{array}{l}\text { Colorful } \\
\text { sandstone }\end{array}$ & $\mathrm{C}_{2} \mathrm{t}$ & $54 / 15$ & $6 / 9$ & $\mathrm{R}$ & 207.3 & -39.1 & 220.0 & -44.4 & 60.0 & 8.7 \\
\hline
\end{tabular}




\begin{tabular}{|c|c|c|c|c|c|c|c|c|c|c|c|c|}
\hline Site & Coordinates & Rocks & Age & Strike/dip & $n / N^{\mathrm{a}}$ & $P$ & Dg & Ig & Ds & Is & $k$ & $\alpha_{95}$ \\
\hline 553 & $\begin{array}{l}43.4^{\circ} \mathrm{N} \\
84.4^{\circ} \mathrm{E}\end{array}$ & Andesite & $\mathrm{C}_{2} \mathrm{t}$ & $54 / 15$ & $6 / 7$ & $\mathrm{R}$ & 216.9 & -32.6 & 226.9 & -35.7 & 179.2 & 5.0 \\
\hline 554 & $\begin{array}{l}43.4^{\circ} \mathrm{N} \\
84.4^{\circ} \mathrm{E}\end{array}$ & Andesite & $\mathrm{C}_{2} \mathrm{t}$ & $54 / 15$ & $6 / 8$ & $\mathrm{R}$ & 204.9 & -38.0 & 217.0 & -44.0 & 124.9 & 4.1 \\
\hline \multirow[t]{2}{*}{ Mean } & & & & & 6 & $\mathrm{R}$ & 211.5 & -36.4 & & & 354.3 & 3.6 \\
\hline & & & & & & & & & 223.1 & -40.8 & 350.1 & 3.6 \\
\hline \multicolumn{13}{|c|}{ Axi area } \\
\hline 510 & $\begin{array}{l}44.2^{\circ} \mathrm{N} \\
81.5^{\circ} \mathrm{E}\end{array}$ & Grey pelite & $\mathrm{O}_{2} \mathrm{l}$ & $290 / 40$ & $9 / 9$ & - & - & - & - & - & - & - \\
\hline 511 & $\begin{array}{l}44.2^{\circ} \mathrm{N} \\
81.5^{\circ} \mathrm{E}\end{array}$ & Grey pelite & $\mathrm{O}_{2} \mathrm{l}$ & $260 / 77$ & $10 / 10$ & - & - & - & - & - & - & - \\
\hline 512 & $\begin{array}{l}44.2^{\circ} \mathrm{N} \\
81.5^{\circ} \mathrm{E}\end{array}$ & Grey pelite & $\mathrm{O}_{2} \mathrm{l}$ & $285 / 78$ & $7 / 8$ & - & - & - & - & - & - & - \\
\hline 513 & $\begin{array}{l}44.2^{\circ} \mathrm{N} \\
81.5^{\circ} \mathrm{E}\end{array}$ & Grey pelite & $\mathrm{O}_{2} \mathrm{l}$ & $80 / 72$ & $7 / 8$ & - & - & - & - & - & - & - \\
\hline 514 & $\begin{array}{l}44.2^{\circ} \mathrm{N} \\
81.5^{\circ} \mathrm{E}\end{array}$ & Grey pelite & $\mathrm{O}_{2} \mathrm{l}$ & $255 / 80$ & $6 / 7$ & - & - & - & - & - & - & - \\
\hline 515 & $\begin{array}{l}44.2^{\circ} \mathrm{N} \\
81.5^{\circ} \mathrm{E}\end{array}$ & $\begin{array}{l}\text { Black } \\
\text { limestone }\end{array}$ & $\mathrm{O}_{2} \mathrm{l}$ & $320 / 58$ & $7 / 7$ & - & - & - & - & - & - & - \\
\hline \multicolumn{13}{|c|}{ Axi area } \\
\hline 516 & $\begin{array}{l}44.2^{\circ} \mathrm{N} \\
81.5^{\circ} \mathrm{E}\end{array}$ & $\begin{array}{l}\text { Black } \\
\text { limestone }\end{array}$ & $\mathrm{O}_{2} \mathrm{l}$ & $320 / 58$ & $8 / 8$ & - & - & - & - & - & - & - \\
\hline 517 & $\begin{array}{l}44.2^{\circ} \mathrm{N} \\
81.5^{\circ} \mathrm{E}\end{array}$ & Red pelite & $\mathrm{O}_{2} \mathrm{l}$ & $320 / 45$ & $6 / 8$ & - & - & - & - & - & - & - \\
\hline
\end{tabular}

Abbreviations: $\mathrm{P}$, polarity; $\mathrm{R}$, reversed; $\mathrm{O}_{21}$, Ordovician Lelengeledaban Formation ( $\left.\mathrm{Fm}\right) ; \mathrm{C}_{1 \mathrm{ak}}$ and $\mathrm{C}_{1 \mathrm{aw}}$ are Early Carboniferous Akeshake Fm and Awulale Fm; $\mathrm{C}_{2 \mathrm{y}}$ and $\mathrm{C}_{2 \mathrm{t}}$ are Late Carboniferous Yishijilike Fm and Tuergong Fm; $\mathrm{P}_{2 \mathrm{x}}$, Late Permian Xiaoshansayi Fm; Dg, Ig, Ds, Is are declination $(D)$ and inclination $(I)$ in geographic $(g)$ and stratigraphic $(s)$ coordinates, $k$ is the best estimate of the precision parameter, $\alpha_{95}$ is the radius that mean direction lies within $95 \%$ confidence.

${ }^{\text {a }} n$, measured sample number; $N$, collected sample number.

${ }^{\mathrm{b}}$ Ages within the parentheses represent the age of remanence.

${ }^{\mathrm{c}}$ Locality-mean direction calculated with 4 in-situ directions of Sites 537-540 and 2 tilt-corrected directions of sites 541 and 542. 
Accepted in Earth Planetary Science Letter

Table 2. Synthesis of Late Carboniferous and Late Permian paleomagnetic poles from the Yili,

Junggar, Tarim and Siberia blocks

\begin{tabular}{|c|c|c|c|c|c|c|c|c|c|}
\hline Blocks & Areas & Ages & Slat & Slong & $N$ & Plat & Plong & $A_{95}$ & References \\
\hline \multirow[t]{4}{*}{ Yili } & Gongliu & $\mathrm{P}_{2}$ & 43.4 & 82.5 & 5 & 79.7 & 172.0 & 11.3 & This study \\
\hline & Zhaosu & $\mathrm{C}_{2}$ & 43.3 & 81.1 & 9 & 72.0 & 287.1 & 8.9 & This study \\
\hline & Xinyuan & $\mathrm{C}_{2}$ & 43.3 & 83.3 & 6 & 63.9 & 296.0 & 9.8 & This study \\
\hline & Mean & $\mathrm{C}_{2}$ & & & 15 & 68.6 & 290.6 & 6.1 & This study \\
\hline \multirow[t]{13}{*}{ Tarim } & Northwest & $\mathrm{P}_{2}$ & 40.2 & 79 & 21 & 65.6 & 181.2 & 3.9 & Li et al. (1989) \\
\hline & Southwest & $\mathrm{P}$ & 37 & 80 & 8 & 65.4 & 170.5 & 8.5 & Gilder et al. (1996) \\
\hline & & $\mathrm{P} 2$ & 40.8 & 79.8 & 24 & 62.9 & 190.7 & 6.3 & Gilder et al. (1996) \\
\hline & & $\mathrm{P} 2$ & & & 20 & 66.0 & 188.8 & 6.3 & Meng (1991) \\
\hline & & $\mathrm{P} 2$ & 42.1 & 83.4 & 10 & 73.2 & 191.0 & 7.3 & Li et al. (1991) \\
\hline & Mean & $\mathrm{P}_{2}$ & & & & 66.8 & 184.1 & 4.9 & \\
\hline & Southwest & $\mathrm{C}_{2}$ & 37 & 80 & 7 & 60.2 & 165.4 & 11.1 & Gilder et al. (1996) \\
\hline & Akesu & $\mathrm{C}_{2}$ & 40.3 & 79.5 & 44 & 52.2 & 179.5 & 8.6 & Van Der Voo (1993) \\
\hline & Akesu & $\mathrm{C}_{2}$ & 40.6 & 79.5 & 9 & 46.5 & 168.0 & 4.6 & Zhao et al. (2003) \\
\hline & & $\mathrm{C}_{2}$ & 40.5 & 78.8 & 3 & 41.0 & 160.0 & 4.0 & Sharps et al. (1992) \\
\hline & & $\mathrm{C}_{2}$ & & & 44 & 61.3 & 174.0 & 4.0 & Nie et al. (1993) \\
\hline & & $\mathrm{C}_{2}$ & & & 22 & 46.6 & 170.2 & 4.5 & Harkand et al. (2005) \\
\hline & Mean & $\mathrm{C}_{2}$ & & & & 51.5 & 169.1 & 7.7 & \\
\hline \multirow[t]{2}{*}{ Siberia } & & $\mathrm{P}_{2}$ & & & 5 & 50.0 & 160.0 & 7.0 & Van Der Voo (1993) \\
\hline & & $\mathrm{C}_{2}$ & & & 17 & 41.0 & 169.0 & 3.0 & Van Der Voo (1993) \\
\hline \multirow[t]{6}{*}{ Junggar } & Tianchi & $\mathrm{P}_{2}$ & 44 & 88.1 & 7 & 76.0 & 193.0 & 4.6 & Nie et al. (1993) \\
\hline & Urumqi $^{\mathrm{a}}$ & $\mathrm{P}_{2}$ & 43.8 & 87.7 & $78^{\mathrm{b}}$ & 77.7 & 0.4 & 5.5 & Sharps et al. (1992) \\
\hline & Northwest ${ }^{\mathrm{c}}$ & $\mathrm{C}_{2}-\mathrm{P}$ & 47.2 & 86.6 & 26 & 69.0 & 350.0 & 7.5 & Li et al. (1991) \\
\hline & Northwest $^{\mathrm{c}}$ & $\mathrm{C}_{2}-\mathrm{P}$ & 45.6 & 83.2 & 23 & 78.0 & 238.7 & 7.9 & Li et al. (1989) \\
\hline & Urumqi $^{\mathrm{c}}$ & $\mathrm{C}_{2}-\mathrm{P}$ & 43.8 & 87.8 & 4 & 69.0 & 231.0 & 13.7 & Li et al. (1991) \\
\hline & Urumqi $^{\mathrm{c}}$ & $\mathrm{C}_{2}-\mathrm{P}$ & 43.8 & 87.8 & 7 & 55.0 & 172.0 & 15.1 & Li et al. (1991) \\
\hline
\end{tabular}


Accepted in Earth Planetary Science Letter

\begin{tabular}{|l|l|l|l|l|l|l|l|l|l|}
\hline Blocks & Areas & Ages & Slat & Slong & $\boldsymbol{N}$ & Plat & Plong & $\boldsymbol{A}_{\mathbf{9 5}}$ & References \\
\hline & Northwest & $\mathrm{C}_{2}$ & 46.7 & 86.1 & 15 & 70.0 & 299.0 & 6.4 & Li et al. (1991) \\
\hline
\end{tabular}

Abbreviations: Slat (Plat) is the latitude of site (pole), Slong (Plong) is the longitude of site (pole); $\alpha_{95}$ is the radius that mean direction lies within $95 \%$ confidence, $\mathrm{N}$ is the number of sites.

Note: a, viscous, only 26 out of 78 samples give directly observed directions of 4 sites, and these directions are dispearsed.Others are analysed with grand circle; b, ages are uncertain; and directions are explained with considerable later overprint; * sample number. 